\title{
Drought Resilience Debt Drives NPP Decline in the Amazon Forest
}

Fausto Machado-Silva, Leonardo F. Peres, Celia M. Gouveia, Alex Enrich Prast, Roberta B. Peixoto, Jose M. C. Pereira, Humberto Marotta, Pedro J. F. Fernandes and Renata Libonati

The published version of this journal article is available at Linköping University Institutional Repository (DiVA):

http://urn.kb.se/resolve?urn=urn:nbn:se:liu:diva-180301

N.B.: When citing this work, cite the original publication.

Machado-Silva, F., Peres, L. F., Gouveia, C. M., Enrich Prast, A., Peixoto, R. B., Pereira, J. M. C., Marotta, H., Fernandes, P. J. F., Libonati, R., (2021), Drought Resilience Debt Drives NPP Decline in the Amazon Forest, Global Biogeochemical Cycles, 35(9), e2021GBo07004.

https://doi.org/10.1029/2021GBo07004

Original publication available at:

https://doi.org/10.1029/2021GBo07004

Copyright: American Geophysical Union

http://sites.agu.org/ 


\section{RESEARCH ARTICLE 10.1029/2021GB007004}

Special Section:

Understanding carbon-climate feedbacks

Key Points:

- Forests undergoing post-drought recovery show lower levels of productivity than undisturbed systems

- Recovery debts vary not only with the degree of intensity of the drought but also with the recovery time after each event

Correspondence to:

F. Machado-Silva and R. Libonati, fausto.eco@gmail.com; renata.libonati@igeo.ufrj.br

Citation:

Machado-Silva, F., Peres, L. F., Gouveia, C. M., Enrich-Prast, A., Peixoto, R. B., Pereira, J. M. C., et al. (2021). Drought resilience debt drives NPP decline in the Amazon forest. Global Biogeochemical Cycles, 35, e2021GB007004. https://doi. org/10.1029/2021GB007004

Received 11 MAR 2021 Accepted 17 AUG 2021
(C) 2021. American Geophysical Union. All Rights Reserved.

\section{Drought Resilience Debt Drives NPP Decline in the Amazon Forest}

\author{
Fausto Machado-Silva ${ }^{1,2}$ (D), Leonardo F. Peres ${ }^{1,3}$, Celia M. Gouveia ${ }^{3,4}$, \\ Alex Enrich-Prast ${ }^{1,5,6}$, Roberta B. Peixoto ${ }^{1,2}$ (D) José M. C. Pereira ${ }^{7}$ (D), \\ Humberto Marotta ${ }^{2,8,9}$, Pedro J. F. Fernandes ${ }^{8}$, and Renata Libonati ${ }^{1,4,7}$
}

${ }^{1}$ Departamento de Meteorologia, Instituto de Geociências, Universidade Federal do Rio de Janeiro, Rio de Janeiro, Brazil, ${ }^{2}$ Programa em Geociências-Geoquímica Ambiental, Universidade Federal Fluminense, Niterói, Brazil, ${ }^{3}$ Instituto Português do Mar e da Atmosfera, Lisbon, Portugal, ${ }^{4}$ Instituto Dom Luiz, Faculdade de Ciências da Universidade de Lisboa, Lisbon, Portugal, ${ }^{5}$ Department of Thematic Studies—Environmental Change, Linköping University, Linköping, Sweden, ${ }^{6}$ Departamento de Botânica, Instituto de Biologia, Universidade Federal do Rio de Janeiro, Rio de Janeiro, Brazil, ${ }^{7}$ Forest Research Centre, School of Agriculture, University of Lisbon, Lisbon, Portugal, ${ }^{8}$ Physical Geography Laboratory, Department of Geography, Graduate Program in Geography, Universidade Federal Fluminense, Niterói, Brazil, ${ }^{9}$ Ecosystems and Global Change Laboratory (LEMG-UFF), International Laboratory of Global Change (LINCGlobal), Biomass and Water Management Research Center (NAB-UFF), Niteroi, Brazil

\begin{abstract}
Climate change has substantially increased the frequency of extreme droughts in the Amazon basin, generating concern about impacts on the world's largest tropical forest, which contributes about one-seventh of the global vegetation carbon sink. Most research to understand drought impacts has focused on the immediate influences of such events, neglecting post-drought effects on ecosystems recovery. Since ecological processes are influenced by antecedent conditions, we analyzed whether extreme droughts affect vegetation growth (i.e., net primary productivity, NPP) recovery. Here, we evaluated the NPP in the Amazon basin from 2003 to 2020, a period in which drought frequency was almost double the decadal incidence of the last century. We show that NPP does respond to the coupled impacts of individual droughts and the post-drought impacts during ecosystem recovery. In particular, our results reveal that the ecosystems undergoing recovery show NPP about 13\% lower than reference values based on the pre-drought state or in areas undisturbed by drought. NPP deficits have consistently increased with the extreme droughts of 2005, 2010, and 2015 due to the combined effects of disturbances magnitude and the length of recovery. If the expected increase in drought frequency and intensity does occur, reduced recovery may lead the Amazon Forest to an alternative ecosystem state with lower carbon uptake, contributing to a warming global climate.
\end{abstract}

Plain Language Summary Extreme droughts cause significant impacts on forest systems. Although drought disturbances are widely quantified, few studies address the impacts of post-drought effects during the recovery period. In this work, we show that forests undergoing post-drought recovery show lower levels of productivity than undisturbed systems. Recovery debts vary with drought intensity and the recovery time after each event. Global warming is projected to increase drought intensity and frequency worldwide and recovery debts may promote a decrease in forests carbon uptake.

\section{Introduction}

Water balance has a major influence on forest productivity and its decline in various parts of the globe has been associated with ongoing global warming. Temperature is a powerful driver of regional forest drought stress caused by persistent precipitation deficit and/or by increased evaporative demand (Vicente-Serrano et al., 2010; Williams et al., 2013). Increasing temperature is also likely to enhance evapotranspiration, reducing soil moisture, and intensifying feedbacks on the water (Zemp et al., 2017) and carbon (C) cycles (Brienen et al., 2015; Feldpausch et al., 2016). In particular, extreme droughts have the strongest negative impacts on vegetation processes, due to their persistence and geographic extent (Hoegh-Guldberg et al., 2018; Vicente-Serrano et al., 2013). Prolonged dry seasons lead to substantial changes across ecosystems, such as tree mortality (Allen et al., 2015; Phillips et al., 2009), fires (Libonati et al., 2021), and decreased photosynthesis (Giardina et al., 2018; J. Yang, Tian, et al., 2018; Zhao \& Running, 2010). Future scenarios indicate 
that climate change will likely increase the global risk of extreme drought events due to global warming impacts on vegetation (Z. Chen et al., 2020; Pokhrel et al., 2021). Considerable uncertainty remains about their possible impacts on tropical forest productivity and capability to absorb atmospheric carbon dioxide $\left(\mathrm{CO}_{2}\right)$ (Barkhordarian et al., 2019; Feldpausch et al., 2016; Giardina et al., 2018; Guan et al., 2015; Nemani et al., 2003; Pokhrel et al., 2021; Saleska et al., 2007; Wigneron et al., 2020).

The Amazon forest has a relevant influence in the global $\mathrm{C}$ cycle and drought-induced changes in aboveground net primary productivity (NPP) is expected to significantly influence the atmospheric concentration of $\mathrm{CO}_{2}$ (Feldpausch et al., 2016; Friedlingstein et al., 2019; Gatti et al., 2014; Zhao \& Running, 2010). Evidence indicates that the Amazon may change from a $\mathrm{CO}_{2}$ sink to a source when there is a significant decrease in NPP in response to extreme droughts (Brienen et al., 2015; C. E. Doughty et al., 2015). In situ (C. E. Doughty et al., 2015; Feldpausch et al., 2016; Santos et al., 2018) and satellite observations (Anderson et al., 2018; Asner et al., 2004; J. Yang, Tian, et al., 2018; Zhao \& Running, 2010) suggest that Amazon forest species may slow their growth rates by reducing $\mathrm{C}$ use efficiency to compensate for low water supply. Tall trees and old trees are less affected by rainfall reduction; however, during prolonged droughts, they can be more affected than understory trees (Giardina et al., 2018; Santos et al., 2018). The ongoing climate changes are expected to increase the temperature, frequency, and intensity of drought in the Amazon, causing further changes in the water and $\mathrm{C}$ cycle in the basin. Extreme precipitation reduction and temperature increase were also documented with regional-scale changes in C stock and C fluxes (Gatti et al., 2021; Wigneron et al., 2020).

River records indicate that the Amazon experienced an extreme drought event every 10 years in the last century and that, recently, in the short span of 10 years, the Amazon Basin was affected by three severe droughts in 2005, 2010, and 2015, all related to anomalous warming in Pacific or Atlantic oceans (Marengo et al., 2011). 20052010 droughts were strongly correlated with anomalous warming due to the Atlantic Multidecadal Oscillation (AMO), and, in the case of 2010, also the El Niño Southern Oscillation (ENSO) (Marengo et al., 2011). In 2015, the extreme ENSO resulted in unprecedented warming and a greater extent of extreme droughts (Jiménez-Muñoz et al., 2016). Although there is still no consensus regarding drought trends over the Amazon, some field observations and numerical models indicate that large-scale deforestation has decreased net surface radiation and evapotranspiration, increasing sensible heat flux, water production, and river discharge in many locations, particularly in the southeastern agricultural frontier (Coe et al., 2016). A recent report indicates that eastern Amazonia has been subjected to more deforestation, warming, and moisture stress than the western part, especially during the dry season, with the southeast experiencing the strongest trends (Gatti et al., 2021). Other trends have been pointed for the region, such as the systematic increase in vapor pressure deficit (Barkhordarian et al., 2019), warming (Jiménez-Muñoz et al., 2016), increased dry season length, and higher frequency of droughts and floods (Marengo et al., 2011).

Extreme droughts differ from the seasonal reduction in precipitation during the dry season. Recent analyses indicate that there is a dry-season green-up in much of the Amazon, which is not tied to extreme droughts but is an annual, seasonal event that occurs regardless of whether there is drought or not. During regular years, the forest often benefited from the reduced cloudiness, suggesting that light limits forest productivity (Nemani et al., 2003; Saleska et al., 2007, 2016). This seasonal green-up was debated but is now generally accepted in light of observations (Gonçalves et al., 2020) and spaceborne solar-induced chlorophyll measurements (R. Doughty et al., 2019, 2021), in addition to the existing eddy tower data (Restrepo-Coupe et al., 2013, 2017) and vegetation index analyses (Saleska et al., 2007, 2016). Dry season length has been increasing during the last decade due to ongoing climate changes and the occurrence of an extreme drought promotes lengthening and intensification of the dry season (Marengo et al., 2011).

Satellite remote sensing provides very useful datasets for monitoring climate variables and NPP responses to the incidence of extreme droughts, reducing uncertainties in the global $\mathrm{C}$ budget, and improving climate predictions (Feldpausch et al., 2016; Friedlingstein et al., 2019; Pokhrel et al., 2021). Recent extreme droughts in the Amazon were simultaneously characterized by a decrease in precipitation, and increases in land surface temperature (LST) and solar radiation (Jiménez-Muñoz et al., 2016; Panisset et al., 2018). In 2005, large areas of southwestern Amazonia experienced one of the most intense droughts of the last 100 years (Marengo et al., 2008), causing increased tree mortality (Phillips et al., 2009) and NPP reduction (Zhao \& Running, 2010). In 2010, the widespread drought in the Amazon was more severe than that of 
2005 (Marengo et al., 2011), also promoting tree mortality (Lewis et al., 2011) and a reduction in NPP and C sequestration (C. E. Doughty et al., 2015). In 2015, record warming was reported and associated with an extreme drought, more severe than the previous two events (Jiménez-Muñoz et al., 2016; Panisset et al., 2018), leading to deficits of vapor pressure in the leaves and loss of gross primary productivity (GPP) associated with reduced soil moisture, especially in the northeast of the basin (van Schaik et al., 2018).

Understanding the response of terrestrial vegetation to the increased frequency of drought is a crucial challenge. Recent evidence indicates that the effects of individual droughts persist for a few years (Anderegg et al., 2015, 2020; Wigneron et al., 2020; Y. Yang, Saatchi, et al., 2018). Past states or experiences may influence the present or future responses of an ecological system, since individuals, adaptations, and materials persist after a disturbance (Ghazoul \& Chazdon, 2017). Resilience debt is the extent to which an ecosystem integrity indicator, such as structure or functional feature is reduced during recovery after a disturbance, indicating the magnitude of ecosystem degradation (Moreno-Mateos et al., 2017). Although several studies point to a continuous increase in the incidence of droughts in the Amazon (Duffy et al., 2015; Hoegh-Guldberg et al., 2018; Pokhrel et al., 2021), most modeling simulations assume invariant post-drought NPP resilience, potentially underestimating drought impacts on vegetation and the $\mathrm{C}$ cycle.

In this study, we assessed Amazon rainforest NPP during a period of a high frequency of extreme droughts, to test whether the ecosystem undergoing recovery would display lower NPP, compared to the reference value existing in the pre-disturbance state or in other ecosystems with similar conditions that remained undisturbed. For this, we also observed gross primary production (GPP) and autotrophic respiration (R) as well as precipitation, LST, solar radiation, and drought indexes. Our main objective is to assess rainforest productivity before and after each drought disturbance, and its recovery in non-drought years, aiming to estimate recovery debts and their relative contribution to total NPP decline.

\section{Material and Methods}

\subsection{Study Area}

The study focuses on the Amazon rainforest across the Amazon River basin, which is delimited by the Andes Mountain range to the west, the Guyana Plateau to the north, and the Brazilian Plateau to the south, with an area of about $6.2 \times 10^{6} \mathrm{~km}^{2}$ (Figure 1). The basin is in the most intense center of precipitation on the planet due to a convective system that is driven by net surface radiation, which is dissipated via fluxes of latent heat and sensible heat. Then, incoming precipitation is balanced by evaporative fluxes of water to the atmosphere and discharge, which returns excess water to the oceans in about an annual period or more (Coe et al., 2016). Between $50 \%$ and $75 \%$ of this precipitation is returned to the atmosphere via evapotranspiration, and the remainder is exported from the basin as river discharge (Zemp et al., 2017). The rainforest is located in the lowlands and represents more than $81 \%$ of the area and other significant vegetation types are herbaceous and woody savanna. The rainforest is classified as an evergreen broadleaf forest according to the Moderate Resolution Imaging Spectroradiometer (MODIS) Global Land Cover Type classification (Sulla-Menashe \& Friedl, 2018). The aboveground biomass usually exceeds $300 \mathrm{Mg} \mathrm{ha}^{-1}$ in the central region, ranges from 150 to $300 \mathrm{Mg} \mathrm{ha}^{-1}$ in western lowlands, and from 100 to $200 \mathrm{Mg} \mathrm{ha}^{-1}$ in the transitional and seasonal forest at the northern and southern edges of the Amazon basin (Saatchi et al., 2007).

\subsection{Data Sets for Estimating Forest C Processes}

We acquired data of NPP and gross primary productivity (GPP), from MODIS GPP/NPP products (MOD17A2[3]HGF) (Running et al., 2015). MOD17A2HGF is a cumulative 8-day composite of values with a 500-m pixel size based on the radiation use efficiency concept that can be potentially used as inputs to data models to calculate vegetation $\mathrm{C}$ processes. The data product includes information about GPP and net photosynthesis, which is calculated as the difference between GPP and maintenance respiration. MOD17A3HGF provides information about annual NPP at 500-m pixel resolution, which is derived from the sum of all 8-day net photosynthesis products (MOD17A2H) calculated as the difference of GPP and the maintenance respiration. MOD17A2[3]HGF uses the gap-filled method that substantially increased the quality of MOD17 by having cleaned the contaminated inputs from the 8-day FPAR/Leaf Area Index (LAI), but the 


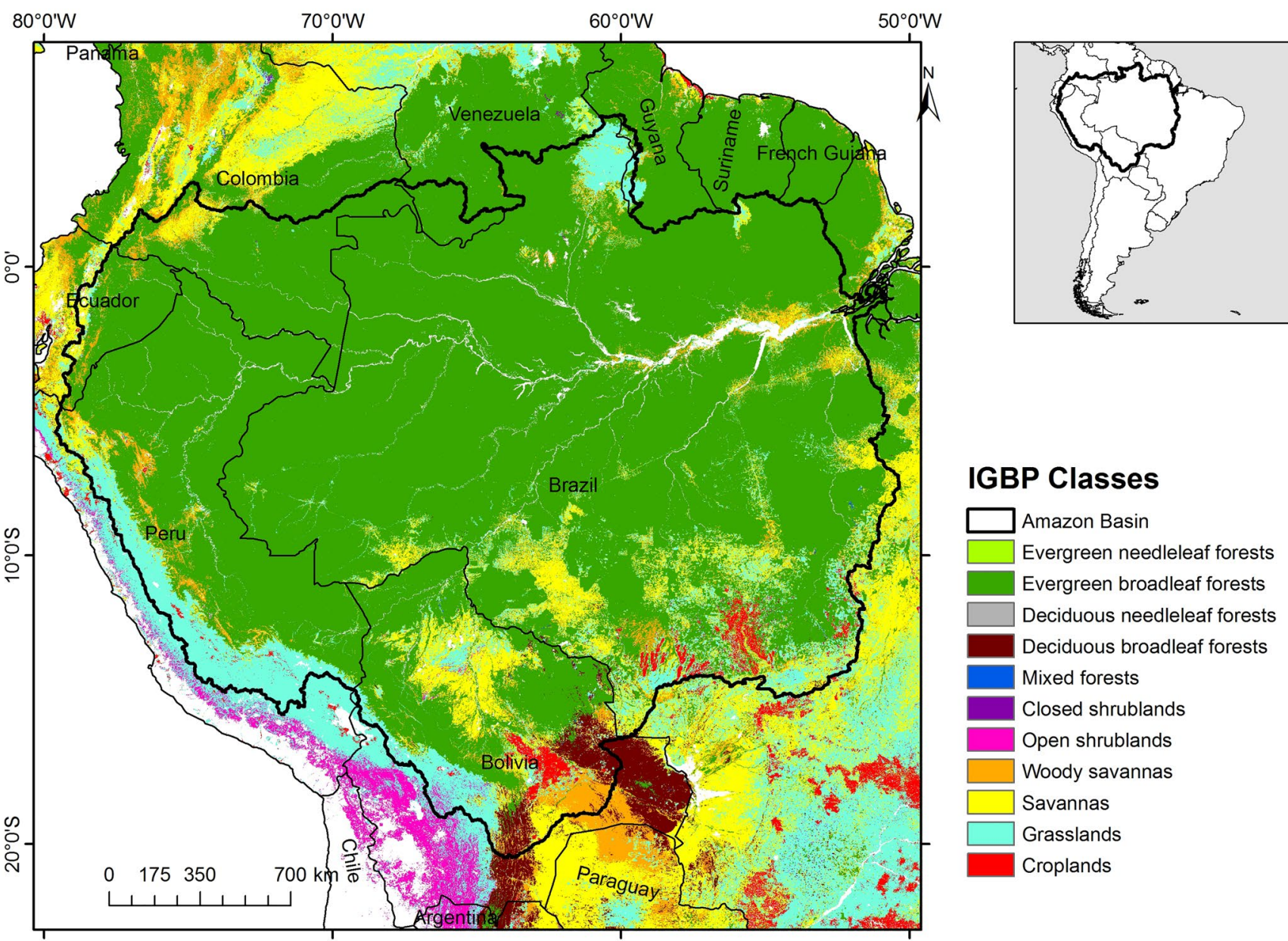

Figure 1. Land cover and land use classes in the Amazon basin. Classes are according to the International Geosphere-Biosphere Programme (IGBP) classification scheme from the MCD12C1 product; the thick black line highlights the Amazon Basin boundary. Amazon rainforest is the evergreen broadleaf forest in dark green.

limitation is that the method can only be applied at the end of the year. Products from 2000 to 2002 did not have the full 8-day data in a year for ideal gap-filling and were excluded from the analysis.

The MODIS GPP/NPP algorithm (Running \& Zhao, 2011; Running et al., 2004, 2011; Zhao \& Running, 2010; Zhao et al., 2005) relies on a light use efficiency model that computes daily GPP as the absorbed photosynthetically active radiation (APAR) multiplied by the light use efficiency $\varepsilon$ (translating energy units to tissue growth). The MOD17A3 product uses the fraction of PAR absorbed by vegetation (fAPAR) and a percentage $(45 \%)$ of the short-wave downward solar radiation, as a surrogate for PAR at the vegetation level, to compute APAR. The effective $\varepsilon$ is a function of reduction scalars based on daily minimum temperature and daylight average vapor pressure deficit that attenuate a tabulated biome-specific maximum light use efficiency $\left(\varepsilon_{\max }\right)$. The respiration $\mathrm{R}$ in the MOD17A3 product has two components, namely daily maintenance respiration and annual growth respiration, where the former is a function of the daily average air temperature. The daily solar radiation, air temperature, and vapor pressure deficit information are from daily global meteorological NCEP-DOE_Reanalysis 2 data provided by the NOAA Physical Sciences Laboratory. Additional MOD17A3 external inputs include APAR and LAI (used to compute leaf mass for estimating maintenance respiration), both from the MODIS MOD15 standard product.

MODIS GPP/NPP data were devised as part of an overall plan to integrate MODIS land data into global terrestrial monitoring, through the interaction with eddy covariance flux tower monitoring (Running et al., 1999). MODIS GPP/NPP product validation is at stage 3, indicating that uncertainties are well quantified from comparison with reference in situ or other suitable reference data (Running et al., 2015). 
Uncertainties, spatial and temporal consistency of the product and consistency with similar products are characterized in a statistically rigorous way over multiple locations and time periods representing global conditions. Validation studies have confirmed that MODIS products are responsive to trends in the magnitude of field GPP/NPP measurement in multiple biome types, including the Amazon region (de Oliveira et al., 2017; Turner, Ritts, Cohen, et al., 2006).

The LST data were extracted from MODIS/Terra Land Surface Temperature, and Emissivity Monthly L3 Global 0.05 Deg CMG V006 product (MOD11C3) (Wan, 2013), available from the NASA Land Processes Distributed Active Archive Center (LP-DAAC). LST measures the emission of thermal radiation from the Earth's surface where incident solar energy interacts with the canopy surface in areas with vegetation or soil (Mildrexler et al., 2009). Precipitation data were obtained from the Tropical Rainfall Measuring Mission (TRMM), multi-satellite precipitation analysis, Monthly 3B43 Rainfall Product V7, at $0.25^{\circ}$ resolution (Huffman et al., 2007), available at https://disc.gsfc.nasa.gov and from the Climate Hazards Group InfraRed Precipitation with Station data that is a rainfall gridded product at 0.05 spatial resolution satellite imagery and in-situ station data, providing near-daily precipitation estimates (Funk et al., 2015). Solar radiation is the monthly shortwave radiation flux at the surface obtained from the European Centre for Medium-Range Weather Forecasts (ECMWF); ERA-Interim reanalysis (Dee et al., 2011); ERA-Interim uses the ECMWF Integrated Forecast Model (IFS Cy31r2), and the data assimilation scheme is based on a 12-hourly four-dimensional variational analysis (4D-Var). The model uses 60 vertical levels with the top of the atmosphere at $0.1 \mathrm{hPa}$, and its spectral resolution is T255 (Dee et al., 2011). These products are highly recommended when data from meteorological stations are insufficient (Huffman et al., 2007), as in the Amazon basin (Panisset et al., 2018).

We computed annual values of NPP, GPP, and R for all grid cells belonging to the evergreen broadleaf forest across the Amazon basin in kilograms of $\mathrm{C}$ per meter squared per year $\left(\mathrm{kg} \mathrm{C} \mathrm{m}^{-2} \mathrm{y}^{-1}\right)$. For this, we used the evergreen broadleaf forest land cover type from the MODIS Land Cover Type Product (MCD12Q1) IGBP classification, which supplies global maps of land cover at annual time steps and 500-m spatial resolution (Shumway \& Stoffer, 2017). We computed the monthly average of the three driest months of each year for each pixel of the study area. Then, we calculated the average values for the entire study area in each year, which resulted in mean monthly precipitation $\left(\mathrm{mm} \mathrm{month}^{-1}\right)$, LST $\left({ }^{\circ} \mathrm{C}\right)$, and solar radiation $\left(\mathrm{W} \mathrm{m}^{-2}\right)$ values.

We extracted the Standardized Precipitation Evapotranspiration Index (SPEI) from Global Drought Monitor (spei.csic.es). The SPEI is based on the difference between precipitation and evapotranspiration and has a multi-scalar character considering the effect of potential evapotranspiration on drought severity, enabling the detection, monitoring, and analysis of droughts according to their intensity and duration to identify different drought types and impacts in the context of global warming (Vicente-Serrano et al., 2010). The SPEI has been previously associated with plant activity on a global scale (Vicente-Serrano et al., 2013) and tree growth in the Amazon rainforest (Feldpausch et al., 2016). Then, to identify areas affected by the three historical droughts we used the 6-month SPEI data to cover the dry season and extension from June to November across the basin in 2005, 2010, and 2015, following previous identification of the Amazon extreme droughts (Feldpausch et al., 2016; Marengo et al., 2011; Panisset et al., 2018). We resampled SPEI data for MODIS resolution using the nearest-neighbor interpolation. Finally, we selected areas with SPEI below -1.5 , which correspond to the highest drought severity classes (Banimahd \& Khalili, 2013; Feldpausch et al., 2016; McKee et al., 1993).

\subsection{Drought Influence on Rainforest NPP}

We address the annual productivity of the evergreen broadleaf forest in the geographical extent of the Amazon basin. We accounted for NPP declines and recovery between areas that were classified as affected (drought area) and non-affected by droughts (undisturbed) based on SPEI data in 2005, 2010, and 2015. All metrics used to describe and quantify the drought process (disturbance and recovery) are defined by using the NPP variability of the drought years $(2005,2010$, and 2015), NPPd, the NPP of the respective previous year $\mathrm{NPP}_{d-1}\left(2004,2009\right.$, and 2014), and the NPP of the subsequent non-drought years $\mathrm{NPP}_{d+t}$ (Figure 2). The drought disturbance $\left(\mathrm{DD}_{d}\right)$ effect on NPP is calculated as the difference in NPP between the drought year $(d)$ and the respective previous year $\left(d^{-1}\right)$ (Asner et al., 2004; Zhao \& Running, 2010) (Equation 1). The 


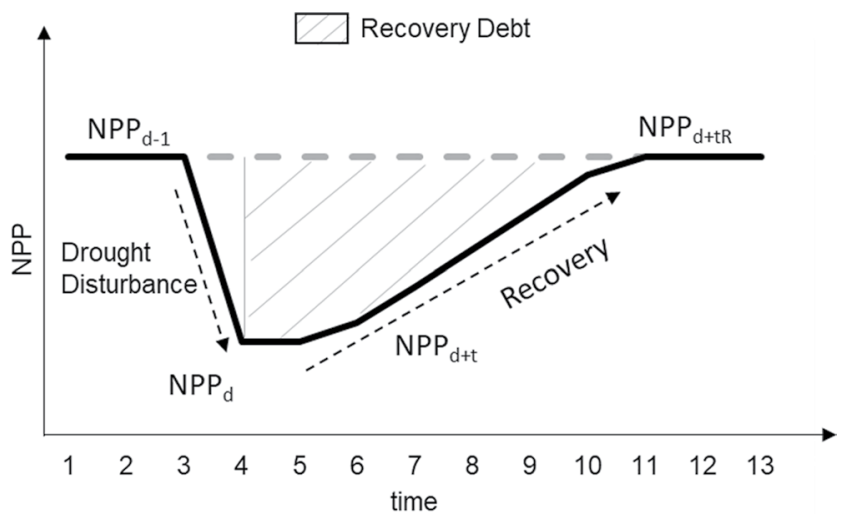

Figure 2. Conceptual model of vegetation net primary productivity (NPP) shaped by dynamics of drought-disturbance and recovery. Hypothetical drought is in time 4 and drought disturbance is the NPP decline from time $3\left(\mathrm{NPP}_{d-1}\right)$ to $4\left(\mathrm{NPP}_{d}\right)$. The dashed gray line represents the reference NPP value existing in the pre-disturbance state $\left(\mathrm{NPP}_{d-1}\right)$ or in another ecosystem with similar conditions that remained "undisturbed." Resilience debt (dashed area) is the interim reduction of NPP occurring during ecosystem recovery from time $4\left(\mathrm{NPP}_{d}\right)$ to $11\left(\mathrm{NPP}_{d+t}\right)$. Conceptual model adapted from Moreno-Mateos et al. (2017). relative contribution of $\mathrm{DD}_{d}$ is related to the respective NPP in the year before the drought $\left(\mathrm{NPP}_{d-1}\right)$. All relative changes are calculated as a ratio and values are expressed in percentage.

$$
\mathrm{DD}_{d}=\mathrm{NPP}_{d}-\mathrm{NPP}_{d-1}
$$

Recovery follows the engineering definition of resilience (Holling, 1996), which can be applied as a proxy for ecological resilience since it also considers the amount of disturbance absorbed before the system changes its self-organized structures and processes (Gunderson, 2000; Holling, 1973; Scheffer et al., 2015). We quantify the NPP recovery from each drought $\left(\mathrm{RC}_{d}\right)$ as the NPP change in the subsequent years $(t)$ until full recovery $(t \mathrm{R})$ after a drought episode $\left(\mathrm{NPP}_{d+t \mathrm{R}}\right)$. Thus, we assess the recovery in NPP for the Amazon droughts by computing the NPP difference between the years after a drought that achieved NPP levels before drought (NP$\left.\mathrm{P}_{d+t}\right)$ and the respective NPP in a drought year $\left(\mathrm{NPP}_{d}\right)$ (Equation 2). The relative change of $\mathrm{RC}_{d}$ is related to $\mathrm{DD}_{d}$.

$$
\mathrm{RC}_{d}=\mathrm{NPP}_{d+t \mathrm{R}}-\mathrm{NPP}_{d}
$$

Recovery debt $\left(\mathrm{RD}_{d}\right)$ is the NPP deficit relative to the value in the year before the last drought (Figure 2). Then, we quantify the NPP recovery debts $\mathrm{RD}_{d}$ as the interim reduction of NPP during ecosystem recovery as the sum of differences between the NPP in the subsequent years $\left(\mathrm{NPP}_{d-1}\right.$, Equation 3). The relative change of $\mathrm{RD}_{d}$ is related to $\mathrm{NPP}_{d-1}$.

$$
\mathrm{RD}_{d}=\Sigma\left(\mathrm{NPP}_{d+t}-\mathrm{NPP}_{d-1}\right)
$$

\subsection{Statistical Analysis of NPP Trends and Drivers}

Trends were evaluated using the nonparametric Theil-Sen robust linear regression (TS) and a two-tailed Mann-Kendall (MK) test of significance (Kendall, 1938; Mann, 1945). The TS estimator is robust against outliers and suitable for application with short time series displaying large interannual variations (Chandler \& Scott, 2011; Yue \& Wang, 2002). The null distribution of the MK test statistics can be approximated by a normal distribution when $n \geq 8$ (Kendall, 1938; Mann, 1945). The standardized $Z$ test statistic follows the standard normal distribution with zero mean and unit variance under the null hypothesis of no trend. A positive $Z$ value indicates an upward trend, whereas a negative value indicates a downward trend. The $p$-value of the MK statistic can then be determined using the normal cumulative distribution function. Then, the spatial NPP trends were computed for the Amazon basin on a pixel basis (500 m). In addition, we test the relationship between carbon processes and climate drivers using simple and multiple linear regression analysis to assess the statistical significance of the relationships between C processes (NPP, GPP, and R) and climate drivers (LST, precipitation, solar radiation). We used Spearman and Pearson correlation to tests the relationship between NPP and R and R and GPP respectively. We also used the Akaike information criterion to select the most parsimonious linear fit. All tests were performed at a significance level of $p<0.05$ in the R environment (R Core Team, 2020).

\section{Results}

\subsection{Interannual Variability of NPP: Drought-Disturbances, Recovery, and Recovery Debts}

First, we observed significant decreases in NPP from 2004 to 2005, 2009 to 2010, and 2014 to 2015 (Figure 3). We estimate DD as an NPP mean (standard deviation, sd) reduction of 0.09 (0.02) and $0.07(0.03)$ $\mathrm{kg} \mathrm{C} \mathrm{m} \mathrm{m}^{-1}$ respectively for pre-drought and undisturbed systems, representing a relative change of 7.5 (1.1)\% and $6.3(2.3) \%$. Second, we observed that NPP displayed a positive trend during post-drought years (Figure 3). Then, we estimated RC as $0.12(0.04)$ and $0.15(0.05)$ for pre-drought and undisturbed reference values, indicating a relative change of $10.5(3.6) \%$ and 11.7 (4.0)\%. Further, we quantified RD as the extent to which NPP values are below reference values in pre-drought and undisturbed systems. On average, RD 

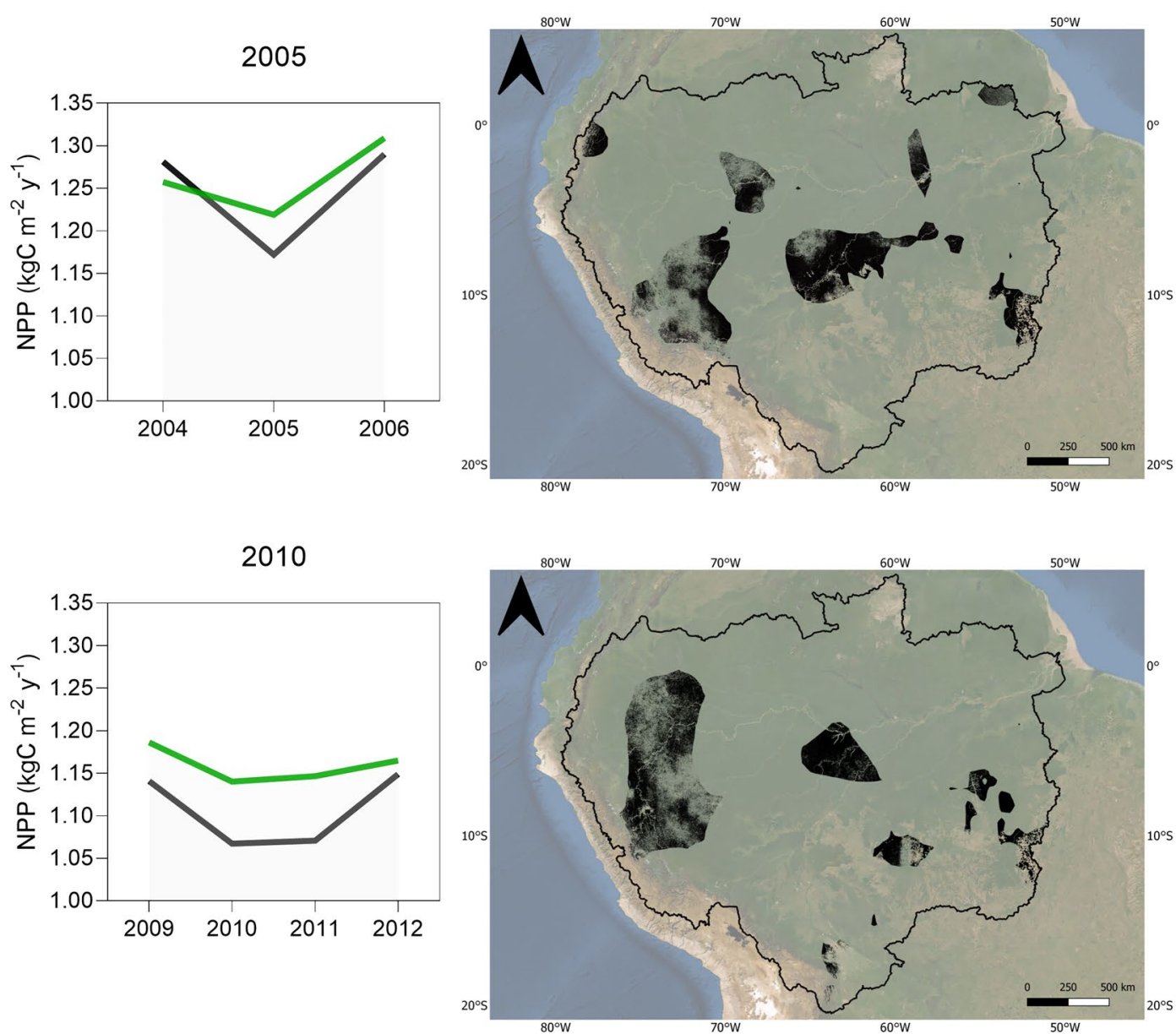

2015
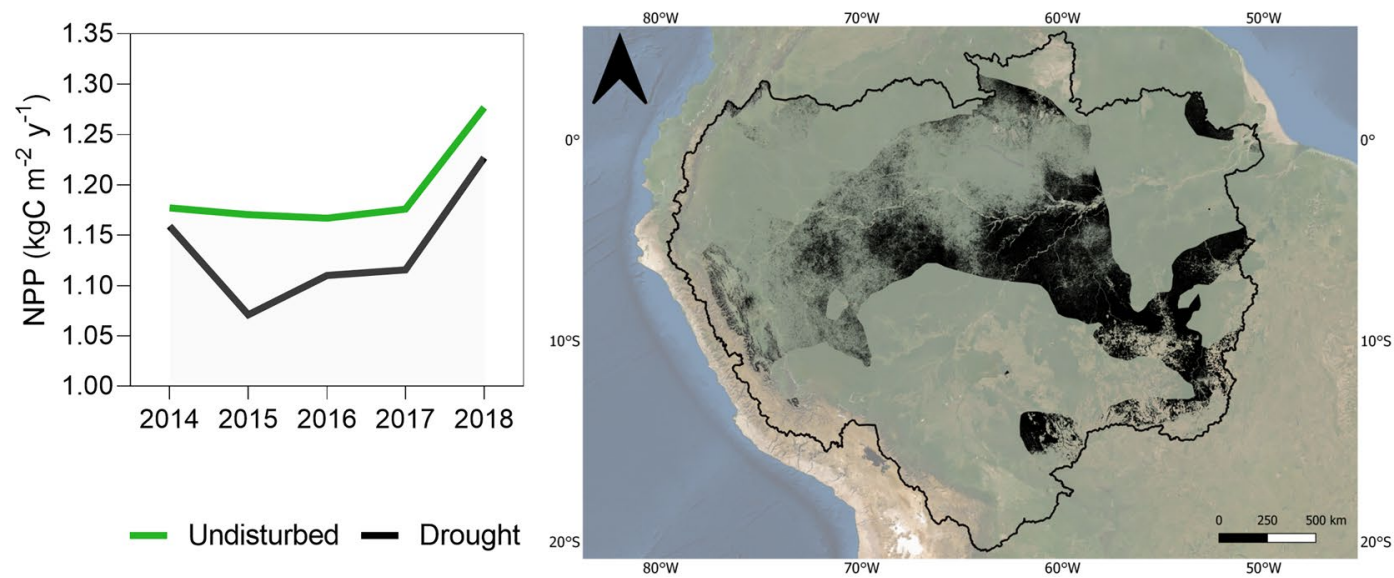

Figure 3. Drought disturbances and resilience debts shape the rainforest net primary productivity $\left(\mathrm{NPP}, \mathrm{kgC} \mathrm{m}^{-2} \mathrm{y}^{-1}\right)$ in the Amazon basin. Graphs show the average NPP of undisturbed areas (green) and disturbed areas by a single drought (black), both 2005 and 2010 (orange), both 2010 and 2015 (yellow), and by the three events (red). Black area in maps indicates drought disturbed areas in each event and the combination of them. 


\begin{tabular}{|c|c|c|c|c|c|}
\hline Drought processes & Reference & Event & Period & $\triangle \mathrm{NPP}$ & Relative change \\
\hline \multirow[t]{6}{*}{ Drought disturbance } & \multirow[t]{3}{*}{ Pre-drought } & 2005 & 2004-2005 & -0.109 & 8.5 \\
\hline & & 2010 & 2009-2010 & -0.074 & 6.3 \\
\hline & & 2015 & 2014-2015 & -0.088 & 7.6 \\
\hline & \multirow[t]{3}{*}{ Undisturbed } & 2005 & $2005-2005^{\mathrm{a}}$ & -0.047 & 3.9 \\
\hline & & 2010 & $2010-2005^{\mathrm{a}}$ & -0.073 & 6.4 \\
\hline & & 2015 & $2015-2015^{\mathrm{a}}$ & -0.100 & 8.5 \\
\hline \multirow[t]{6}{*}{ Recovery } & \multirow[t]{3}{*}{ Pre-drought } & 2005 & $2006-2005$ & 0.118 & 9.2 \\
\hline & & 2010 & $2012-2010$ & 0.082 & 7.7 \\
\hline & & 2015 & $2018-2015$ & 0.156 & 14.6 \\
\hline & \multirow[t]{3}{*}{ Undisturbed } & 2005 & $2006^{\mathrm{a}-2005}$ & 0.137 & 10.5 \\
\hline & & 2010 & $2012^{\mathrm{a}-2010}$ & 0.098 & 8.4 \\
\hline & & 2015 & $2018^{\mathrm{a}}-2015$ & 0.206 & 16.1 \\
\hline \multirow[t]{6}{*}{ Recovery debts } & \multirow[t]{3}{*}{ Pre-drought } & 2005 & $2005-2004 \rightarrow 2006-2004$ & -0.109 & 8.5 \\
\hline & & 2010 & $2010-2009 \rightarrow 2012-2009$ & -0.144 & 12.6 \\
\hline & & 2015 & $2015-2014 \rightarrow 2017-2014$ & -0.181 & 15.5 \\
\hline & \multirow[t]{3}{*}{ Undisturbed } & 2005 & $2005-2005^{\mathrm{a}}$ & -0.047 & 3.9 \\
\hline & & 2010 & $2010-2010^{\mathrm{a}} \rightarrow 2012-2012^{\mathrm{a}}$ & -0.165 & 14.5 \\
\hline & & 2015 & $2015-2015^{\mathrm{a}} \rightarrow 2018-2018^{\mathrm{a}}$ & -0.267 & 22.8 \\
\hline
\end{tabular}

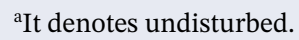

represents a reduction of $0.14(0.04)$ and $0.16(0.11) \mathrm{kg} \mathrm{C} \mathrm{m}^{-2} \mathrm{y}^{-1}$, indicating 12.2 (3.5)\% and 13.7 (9.5)\% respectively to pre-drought and undisturbed systems. RD displayed an ascending order from 2005, 2010, and 2015, and on average RD of 2015 was 1.8 and 1.2 times that estimated for 2005 and 2010 (Table 1).

\subsection{Interannual Variability of Forest $\mathbf{C}$ Processes and Climate Drivers}

The interannual variability of forest $\mathrm{C}$ processes revealed a distinct variability in the study period. For instance, NPP showed a significant negative trend in 2003-2015 period (Theil-Sen regression analysis, $p<0.01$ and the Mann-Kendall correlation test, $\tau=-0.59, p<0.001$, Figure 4a). GPP did not display a marked trend in the 2003-2020 period (Theil-Sen regression analysis, $p>0.05$, Figure $4 \mathrm{~b}$ ). Unlike NPP variability, GPP values in 2005,2010 , and 2015 were higher than in 2004, 2009, and 2014, respectively. The interannual variability of $\mathrm{R}$ showed a significant positive trend in the period 2003-2020 (Theil-Sen regression analysis, $p<0.001$ and the Mann-Kendall correlation test, $\tau=0.58, p<0.001$, Figure 4c). In addition, $\mathrm{R}$ values in 2005, 2010, and 2015 were consistently higher than those of 2004, 2009, and 2014 as well as higher than modeled values.

In addition, dry season precipitation averaged (sd) $99( \pm 9) \mathrm{mm} \mathrm{month}^{-1}$ in drought years, which represents a reduction of approximately $11 \%$ compared to the average of $110( \pm 13) \mathrm{mm} \mathrm{month}^{-1}$. The difference between the dry season precipitation of a drought year and each pre-drought year was $24( \pm 5)$ $\mathrm{mm}$ (Figure 5a). Dry season LST averaged (sd) $23.5( \pm 0.8)^{\circ} \mathrm{C}$ in drought years, representing an increase of approximately $1.6 \%$ relative to the average $(\mathrm{sd})$ of $23.1( \pm 0.5)^{\circ} \mathrm{C}$. Increases in LST in drought years, compared to pre-drought levels, were $0.6( \pm 0.4)^{\circ} \mathrm{C}$. We observed a significant positive LST trend in the 2000-2015 period (Theil-Sen regression, $p$-value $<0.001$, and Mann-Kendall test, $\tau=0.6, p<0.01$, Figure 5b). Finally, dry season solar radiation averaged (sd) $207( \pm 9) \mathrm{W} \mathrm{m}^{-2}$ in drought years, which repre- 

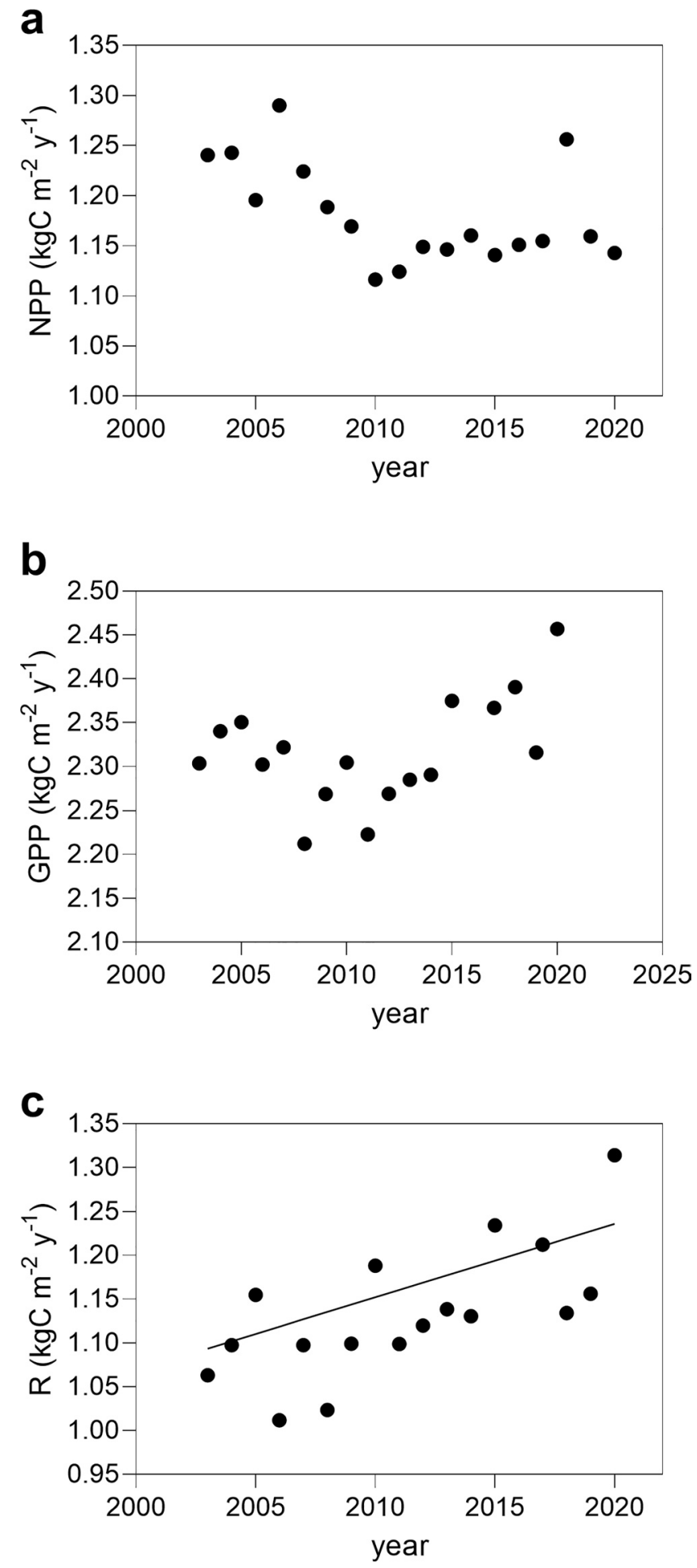

Figure 4. Interannual variability of forest carbon processes $\left(\mathrm{kgC} \mathrm{m}^{-2} \mathrm{y}^{-1}\right)$. (a) NPP is net primary productivity. (b) GPP is gross primary productivity. (c) $\mathrm{R}$ is autotrophic respiration. The black line shows the $\mathrm{R}$ trend (TheilSen regression analysis, slope $=0.008, p<0.001$ and the Mann-Kendall correlation test, $\tau=0.58, p<0.0001)$. sents an increase of approximately $1.6 \%$, compared to the average of 204 $( \pm 8) \mathrm{W} \mathrm{m}^{-2}$. Solar radiation increased relatively to pre-drought levels by $4.8( \pm 5.6) \mathrm{W} \mathrm{m}^{-2}$ (Figure 5c).

\subsection{Interrelationships Between Forest $\mathrm{C}$ Processes, and the Influence of Climatic Drivers}

We observed a wide scattering of data in the graph of NPP versus GPP (Figure 6a). We observed a significant negative correlation between NPP and $\mathrm{R}$ (Spearman correlation, $r_{\mathrm{s}}=-0.62, p<0.01$, Figure $6 \mathrm{~b}$ ) and a significant positive relationship between $\mathrm{R}$ and GPP (Pearson correlation, $r=0.74$, $p<0.001$, Figure 6c). The linear model shows that the increase of one unit in GPP is followed by 0.9 in R (Linear regression analyses, $r^{2}=0.54$, $p<0.0001$, Figure 6c). In addition, the investigation of the influence of climate drivers during the NPP fall from 2003 to 2005 showed that LST and solar radiation are more influential drivers of carbon processes (Figure 7). As expected, GPP was positively related to dry season solar radiation (linear regression analyses, $r^{2}=0.69, p<0.0001$, Figure 7f). Conversely, R was positively related to dry season LST (linear regression analyses, $r^{2}=0.45$, $p<0.05$, Figure $7 \mathrm{~h}$ ) and negatively related to dry season precipitation (linear regression analyses, $r^{2}=0.36, p<0.05$, Figure $7 \mathrm{~g}$ ). In the case of NPP, although climate drivers did not predict NPP separately (Figure 7), we observed a significant influence of dry season solar radiation (SR) and LST when combined in the multiple regression model (Table 2).

\subsection{NPP Spatial Variability}

The spatial patterns of drought disturbances revealed the most affected regions at each event (Figure 3). For instance, in 2005, about $8.5 \%$ of the basin was affected by drought disturbances, an area of $0.53 \times 10^{6} \mathrm{~km}^{2}$. Large areas were affected in southwestern and in central Amazon in addition to others in northwestern, northeastern, and southeastern. In 2010 , about $8.4 \%$ of the basin was affected by drought disturbances, an area of $0.52 \times 10^{6} \mathrm{~km}^{2}$. We observed a large extent of NPP decreases in the western Amazon in addition to a mid-size patch in the central Amazon and smaller patches in the south and southeast regions. In 2015, about $16.7 \%$ of the basin suffered drought disturbances, an area of $1.04 \times 10^{6} \mathrm{~km}^{2}$. The drought disturbances occurred in a large area that covers the western, central, north, and southeastern Amazon as well as in other areas in the south and northeast.

We observed significant negative NPP trends in approximately $0.96 \times 10^{6} \mathrm{~km}^{2}$ or $15.5 \%$ of the Amazon basin and positive trends at $0.65 \times 10^{6} \mathrm{~km}^{2}$ or $10.5 \%$ of the basin. The negatively affected areas are located mainly in the central-western, central, central-eastern, and northeastern parts of the basin, in addition to areas nearby the uplands in the southwestern and northwestern, which are dominated by dense evergreen broadleaf forest (Figure 1). This contrasts strikingly with positive trends near the south edges of the basin, covered by savannas, woody savannas, deciduous broadleaf forests, grasslands, and croplands (Figure 8a). NPP negative trends were observed at locations where rainfall exceeds $2,000 \mathrm{~mm} \mathrm{y}^{-1}$ while positive trends are mostly located where rainfall is below $2,000 \mathrm{~mm} \mathrm{y}^{-1}$ (Figure $8 \mathrm{~b}$ ). 
a

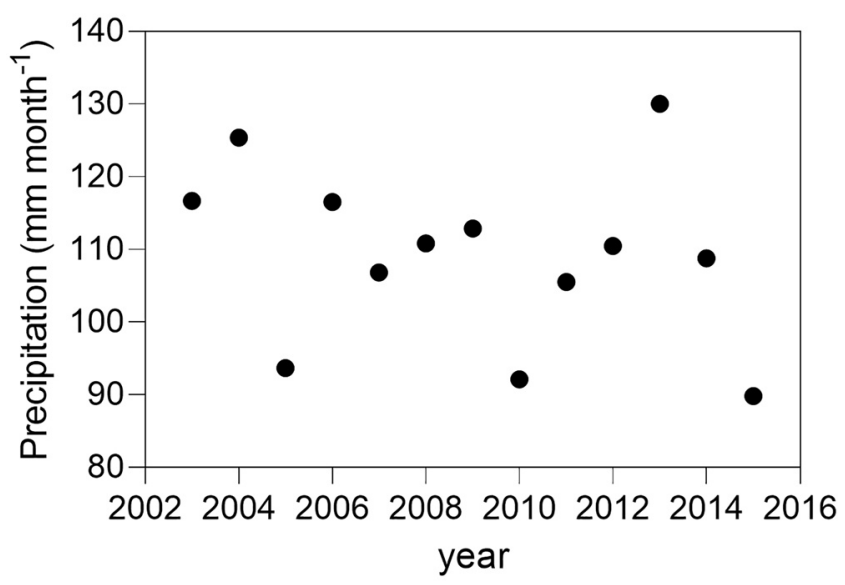

b

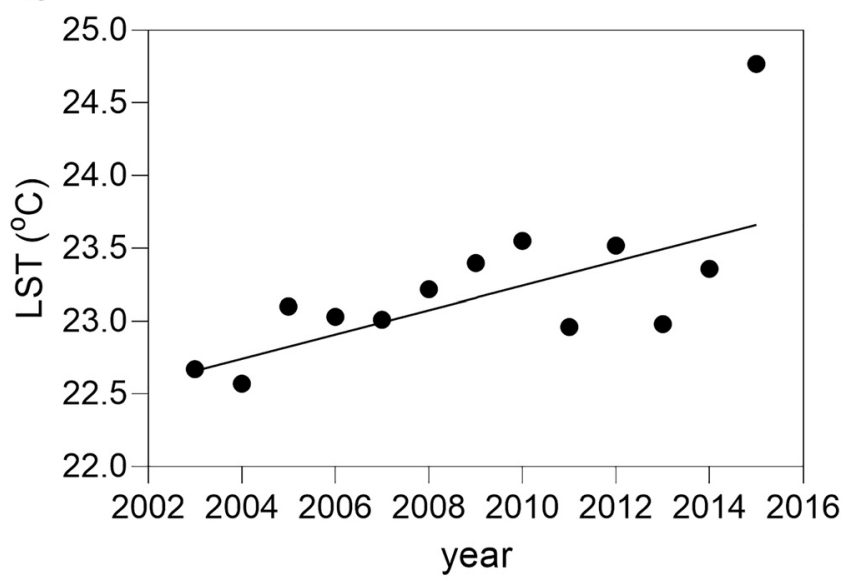

C

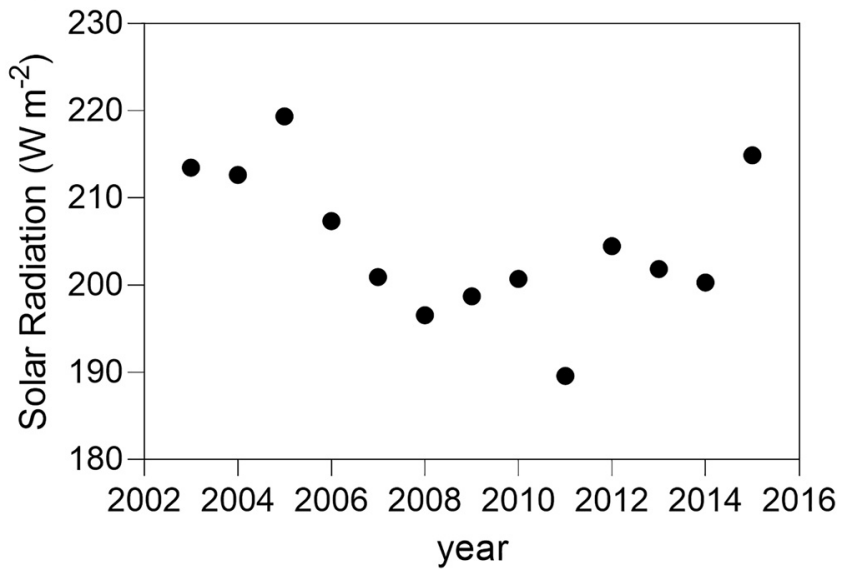

Figure 5. Interannual variability of climate drivers of forest $\mathrm{C}$ processes during the dry season (3 driest months). (a) Precipitation (mm month ${ }^{-1}$ ). (b) Land surface temperature (LST, $\left.{ }^{\circ} \mathrm{C}\right)$. The black line shows LST trend (Theil-Sen regression analysis, slope $=0.08, p$-value $<0.001$, and the Mann-Kendall correlation test, $\tau=0.6, p<0.01$ ). (c) Dry season solar radiation $\left(\mathrm{W} \mathrm{m}^{-2}\right)$.

\section{Discussion}

The Amazon forest is facing more frequent and more severe droughts than other forested biomes in the twenty-first century (Pokhrel et al., 2021; Zemp et al., 2017; Zhao \& Running, 2010) and has been reported as more vulnerable than in the past due to higher temperatures (Davidson et al., 2012; Huang et al., 2019; Saatchi et al., 2021). The change in forest sensitivity to precipitation variability may be associated with the recent intensification of the hydrological cycle with ongoing global warming (Zemp et al., 2017). However, the vulnerability of tropical forests to the recent incidence of droughts remains controversial. Some authors have suggested that the decrease in precipitation, and in associated cloudiness, might favor tree growth limited by the availability of solar radiation (Li et al., 2018; Nemani et al., 2003; Saleska et al., 2016). Other authors have shown that droughts decrease rainforests' C-uptake (C. E. Doughty et al., 2015; Feldpausch et al., 2016; Wigneron et al., 2020). In addition, post-drought resilience adds more complexity to this issue, as recent evidence indicates that historical exposure to rainfall variability may determine system resilience (Ciemer et al., 2019). Here, we observed the negative impact of droughts events on rainforest NPP that is shown by (a) NPP declines in 2005, 2010, and 2015 across areas affected by droughts and (b) lower NPP in affected areas than reference values of pre-droughts and undisturbed locations (Figure 3). This result agrees with previous analyses that associate drought and NPP declines in 2005 and 2010 (C. E. Doughty et al., 2015; Feldpausch et al., 2016), and 2015 (Wigneron et al., 2020). The current observed decline in the Amazon rainforest $\mathrm{C}$ uptake has been associated with an increase in global atmospheric $\mathrm{CO}_{2}$ concentration (Feldpausch et al., 2016; Gatti et al., 2021; Zhao \& Running, 2010).

Rainforests are reported as highly productive and resilient depending heavily on water availability (Poorter et al., 2016). In particular, the Amazon rainforest has deep root systems that allow access to groundwater, which can promote both drought resistance and resilience (Z. Chen et al., 2020; Giardina et al., 2018; Li et al., 2020). In addition, high functional diversity (Sakschewski et al., 2016) and high competition within the canopy (Levine et al., 2016) are also mentioned as ecological features determining rainforest drought-resilience. However, from 2003 to 2020, drought incidence was much higher than over any period of comparable length during the last century (Marengo et al., 2011). Indeed, NPP showed a positive trend after each drought episode, indicating a resilient ecosystem response, recovering in the year after the 2005 drought, in 2 years after the 2010 drought, and in 4 years after that of 2015 (Figure 3). We observed that ecosystems undergoing recovery had NPP about 5\% lower pre-drought levels and $6 \%$ lower undisturbed systems. In addition, we observed that recovery debts increased from 2005-2006 to 2010-2012 and from 2010-2012 to 2015-2018 recovery period (Table 1), which is in line with previous analyzes that show an intensification of the effects of droughts in the Amazon (Anderson et al., 2018). These results suggest that although the Amazon Forest is considered a drought-resilient ecosystem, it can gradually lose productivity in case of resilient debt increase due to combined effects of drought disturbance increase and recovery decrease (Figure 2). 
a

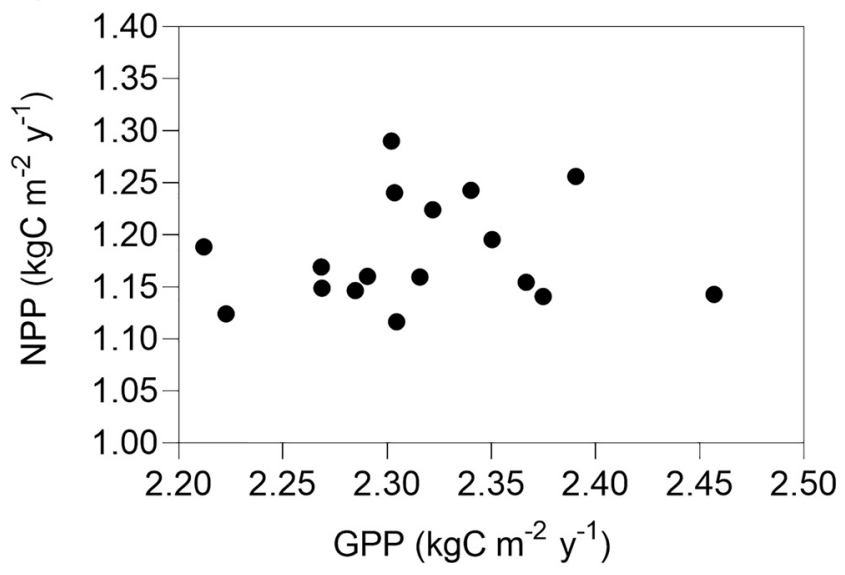

b
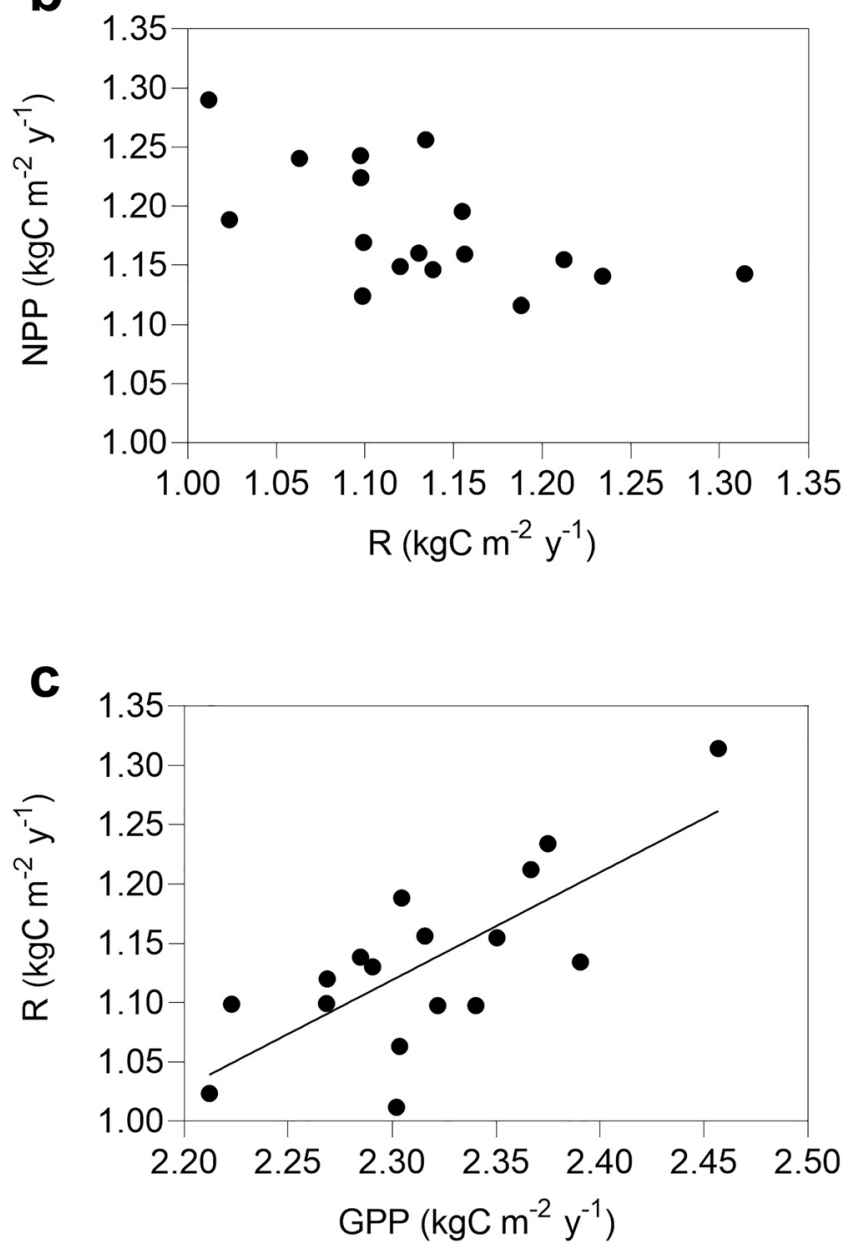

Figure 6. Interrelationship between forest carbon processes $(\mathrm{kg} \mathrm{C}$ $\mathrm{m}^{-2} \mathrm{y}^{-1}$ ). NPP and GPP are net and gross primary productivity, and $\mathrm{R}$ is autotrophic respiration. Each dot represent 1 year. (a) NPP versus GPP. (b) NPP versus R show significant Spearman correlation $\left(r_{s}=-0.62, p<0.01\right)$. (c) R versus GPP. The black line shows linear regression analysis $(r=0.74$, $\left.r^{2}=0.54, p<0.001\right)$.
Photosynthesis may decrease through stomatal closure depressing GPP, and consequently NPP, as a strategy to maintain leaf water potential under high vapor pressure deficit conditions (Santos et al., 2018; Smith et al., 2020). When the stomata close, they interrupt the $\mathrm{CO}_{2}$ supply but not the production of $\mathrm{O}_{2}$, and gas concentration changes favor photorespiration, which consumes $\mathrm{O}_{2}$ and releases $\mathrm{CO}_{2}$. In turn, contrasting $\mathrm{R}$ responses were observed in drought experiments, which showed a decrease in root and stem respiration (C. E. Doughty et al., 2015), but increases in leaf respiration (da Costa et al., 2014). Ground observations also indicate that NPP is dependent on local rainfall and temperature, influencing water availability for vegetation (C. E. Doughty et al., 2015). We observed that the combined surface temperature and solar radiation significantly influenced the NPP values in the period 2003-2015 when there was a significant decrease in the average NPP on a basin-wide scale, suggesting an indirect influence of both factors that were strictly related to GPP and R respectively (Figure 7), which is consistent with light use efficiency theory (Running \& Zhao, 2015; Running et al., 2015). In addition, the observed negative relationship between NPP and R (Figure 6b) further indicates that a decline in NPP is related to respiration increase (C. E. Doughty et al., 2015), which is in line with previous evidence that larger trees decrease growth efficiency as a response to an increase in surface temperature (Santos et al., 2018). The observed increase in surface temperature across the Amazon (Figure 5b) is in agreement with previous studies (Jiménez-Muñoz et al., 2016). The temperature showed to be a significant driver of regional NPP drought stress by enhancing $\mathrm{R}$ (Figure 7h). These results are in line with changes in forest structure and functioning already observed in the 21st century and the transition of forests to a decrease in carbon absorption will potentially be intensified by ongoing global warming (Williams et al., 2013).

The extensive debate over the contrasting responses of the Amazon Forest to droughts is due to different phenomena that occur at various time scales. The vegetation canopy of the Amazon rainforest is highly sensitive to interannual changes in precipitation and evapotranspiration (Hilker et al., 2014). The intensification of the dry season and an increase in deforestation seem to promote ecosystem stress, increasing $\mathrm{C}$ losses (Gatti et al., 2021; Y. Yang, Saatchi, et al., 2018), in agreement with studies that indicate an increase in tree mortality (Lewis et al., 2011; Phillips et al., 2009) and a reduction in photosynthesis (C. E. Doughty et al., 2015; Feldpausch et al., 2016). However, intra-annual variability of photosynthesis indicates a peak after the dry season and a minimum in the rainy season, suggesting dry season green-up and photosynthesis decline in case of higher rainfall (R. Doughty et al., 2021; Nemani et al., 2003; Saleska et al., 2016). The reduction in rainfall observed may benefit vegetation from the reduction of cloudy cover at the first moment while there is still moisture in the soil triggering vegetation phenological variation ( $R$. Doughty et al., 2021; Saleska et al., 2016). Here, we have seen consistent reductions in NPP because of extreme droughts driven by ENSO and/ or AMO events, suggesting that an improvement in the dry season GPP increase is compensated by the subsequent decline during the early wet season, in addition to marked increases in R (Figure 4c). A substantial reduction in rainfall and increases in evapotranspiration may delay soil moisture recovery in the rainy season promoting water stress for plants growth (T. Chen et al., 2013; van Schaik et al., 2018). 
a

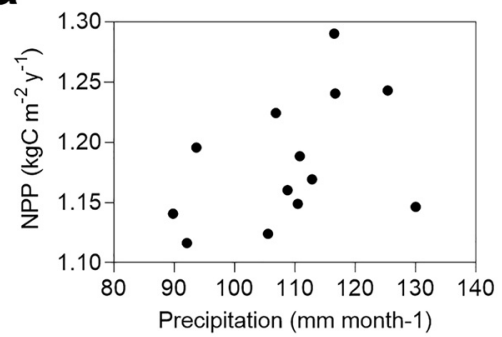

d

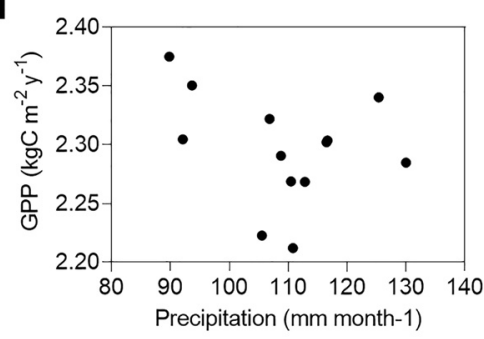

g

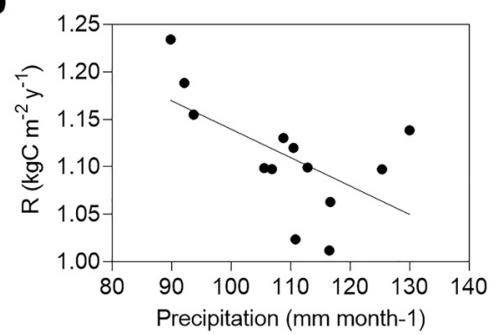

b

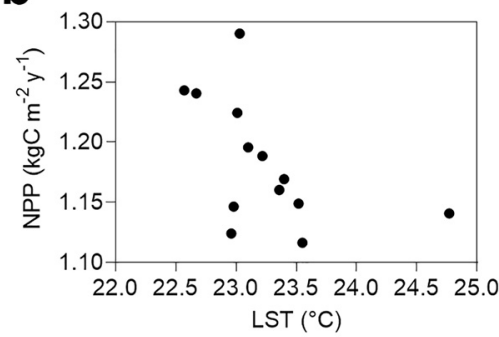

e

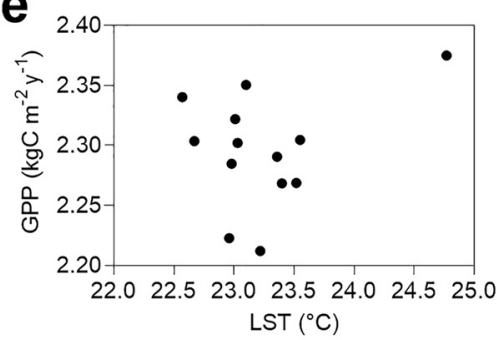

h

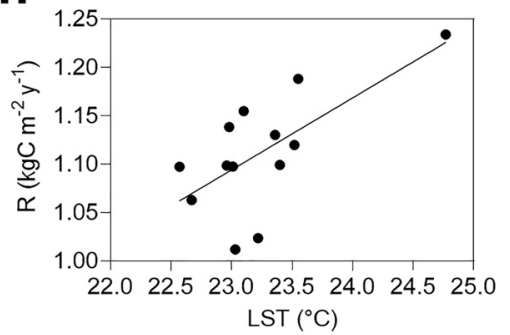

C

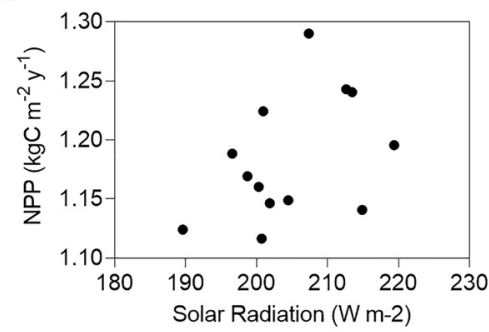

f

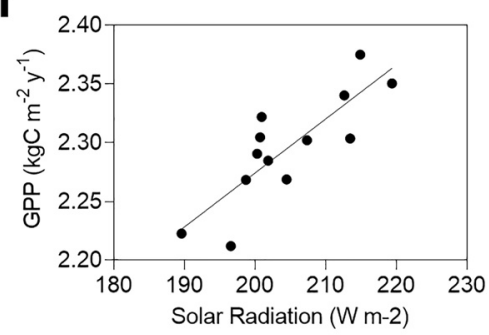

i

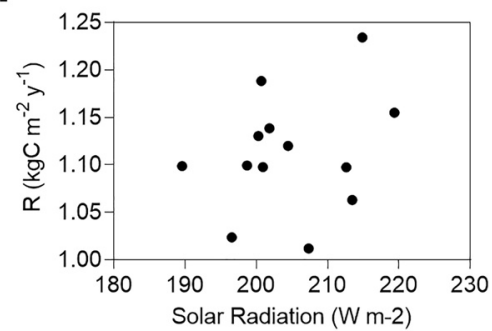

Figure 7. Climate drivers influence forest $\mathrm{C}$ processes. NPP is the net primary productivity $(\mathrm{a}-\mathrm{c})$, GPP is gross primary productivity (d-f), and R is autotrophic respiration (g-i) estimated in $\mathrm{kgC} \mathrm{m}^{-2} \mathrm{y}^{-1}$. Climate drivers are estimated during the dry season: rainfall (mm month ${ }^{-1}$, a, d, g), land surface temperature (LST in ${ }^{\circ} \mathrm{C}, \mathrm{b}, \mathrm{e}, \mathrm{h}$ ), and solar radiation ( $\left.\mathrm{W} \mathrm{m}^{-2}, \mathrm{c}, \mathrm{f}, \mathrm{i}\right)$. Black lines show a significant linear relationship in GPP versus solar radiation, $\mathrm{R}$ versus rainfall, and $\mathrm{R}$ versus LST (linear regression analysis, $p<0.05$ ).

The spatial patterns of drought disturbance for each drought year revealed the regions most affected in each event: western and central Amazon in 2005, 2010, and 2015, and northeastern Amazon in 2015 (Figure 3), in agreement with the areas that displayed negative precipitation anomalies and positive LST anomalies in 2005, 2010, and 2015 (Anderson et al., 2018; Panisset et al., 2018). Approximately 15.5\% of the Amazon basin showed significant negative NPP trends during the period analyzed, located mainly in the central-western, central-northeastern, and Andean boundaries in western parts of the basin (Figure 8a), which are dominated by dense evergreen broadleaf forest (Figure 1) that have been observed as sustained by annual precipitation that exceeds $2,000 \mathrm{~mm} \mathrm{y}^{-1}$ (Guan et al., 2015). This result suggests that rainforests adapted to high precipitation suffer from greater losses of NPP due to current climate changes in the region such as the increase in surface temperature and increase in the oscillation of dry season precipitation. This reveals a novel spatial pattern of productivity decline outside the southern and southeastern sections of the basin, which have undergone extensive land-use transitions, in addition to climate change impacts such as increases in the occurrence of drought and fires (Ciemer et al., 2019; Davidson et al., 2012; Libonati et al., 2021). Specifically, we observed that a significant reduction in productivity occurred at the same locations previously identified as being under drought conditions (Panisset et al., 2018). Furthermore, we do not discard the influence of deforestation-induced feedbacks on NPP depression, since the reduction in evapotranspiration due to land cover changes represents a significant fraction of the Amazon water recycling (Davidson et al., 2012; Ponce-Campos et al., 2013; Zemp et al., 2017). 


\section{Table 2}

Summary of Linear Models of the Relationships Between Forest Carbon Processes (NPP, GPP, and R, $\mathrm{kgC} \mathrm{m}^{-2} \mathrm{y}^{-1}$ ) of the Amazon Rainforest at the Basin-Wide Scale During the NPP Decrease in 2003-2015 Period

\begin{tabular}{|c|c|c|c|c|c|c|c|}
\hline Model & $a$ & $b$ & $c$ & $d$ & $r^{2}$ & $p$-value & AIC \\
\hline $\mathrm{NPP}=a+b \mathrm{P}$ & $2.35(0.57)$ & $-0.05(0.02)$ & & & 0.27 & 0.0667 & -38.9 \\
\hline $\mathrm{NPP}=a+b \mathrm{LST}$ & $0.98(0.13)$ & $0.001(0.001)$ & & & 0.18 & 0.1497 & -37.3 \\
\hline $\mathrm{NPP}=a+b \mathrm{SR}$ & $0.639(0.348)$ & $0.0026(0.0016)$ & & & 0.18 & 0.1457 & -37.4 \\
\hline $\mathrm{NPP}=a+b \mathrm{P}+c \mathrm{LST}$ & $2.08(0.916)$ & $0.0005(0.0015)$ & $-0.041(0.034)$ & & 0.28 & 0.1881 & -37.1 \\
\hline $\mathrm{NPP}=a+b \mathrm{LST}+c \mathrm{SR}$ & $1.84(0.546)$ & $-0.055(0.021)$ & $0.003(0.001)$ & & 0.51 & 0.0286 & -42.0 \\
\hline $\mathrm{NPP}=a+b \mathrm{P}+c \mathrm{SR}$ & $0.3159(0.346)$ & $0.002(0.001)$ & $0.003(0.0015)$ & & 0.42 & 0.0652 & -39.9 \\
\hline $\mathrm{NPP}=a+b \mathrm{P}+c \mathrm{LST}+d \mathrm{SR}$ & $1.437(0.836)$ & $0.0008(0.0013)$ & $-0.0425(0.029)$ & $0.003(0.001)$ & 0.53 & 0.0670 & -40.6 \\
\hline $\mathrm{GPP}=a+b \mathrm{P}$ & $2.421(0.122)$ & $-0.0011(0.0011)$ & & & 0.09 & 0.3258 & -39.07 \\
\hline $\mathrm{GPP}=a+b \mathrm{LST}$ & $1.733(0.572)$ & $0.0242(0.02461)$ & & & 0.08 & 0.3466 & -38.97 \\
\hline $\mathrm{GPP}=a+b \mathrm{SR}$ & $1.355(0.190)$ & $0.0046(0.0009)$ & & & 0.69 & 0.0004 & -53.16 \\
\hline $\mathrm{GPP}=a+b \mathrm{P}+c \mathrm{LST}$ & $2.070(0.911)$ & $-0.0007(0.0015)$ & $0.0134(0.0340)$ & & 0.10 & 0.5852 & -37.27 \\
\hline $\mathrm{GPP}=a+b \mathrm{LST}+c \mathrm{SR}$ & $0.9868(0.3589)$ & $0.0169(0.0141)$ & $0.0045(0.0009)$ & & 0.73 & 0.0014 & -52.91 \\
\hline $\mathrm{GPP}=a+b \mathrm{P}+c \mathrm{SR}$ & $1.4614(0.2118)$ & $-0.0007(0.0006)$ & $0.0045(0.0009)$ & & 0.72 & 0.0016 & -52.61 \\
\hline $\mathrm{GPP}=a+b \mathrm{P}+c \mathrm{LST}+d \mathrm{SR}$ & $1.1495(0.5577)$ & $-0.0003(0.0009)$ & $0.0118(0.0195)$ & $0.0044(0.0010)$ & 0.73 & 0.0058 & -51.13 \\
\hline $\mathrm{R}=a+b \mathrm{P}$ & $1.4379(0.1349)$ & $-0.0029(0.0012)$ & & & 0.35 & 0.0335 & -36.46 \\
\hline $\mathrm{R}=a+b \mathrm{LST}$ & $-0.6176(0.5814)$ & $0.0744(0.0250)$ & & & 0.45 & 0.0126 & -38.56 \\
\hline $\mathrm{R}=a+b \mathrm{SR}$ & $0.7162(0.4303)$ & $0.0019(0.0021)$ & & & 0.07 & 0.3769 & -31.84 \\
\hline $\mathrm{R}=a+b \mathrm{P}+c \mathrm{LST}$ & $-0.0169(0.9019)$ & $-0.0013(0.0015)$ & $0.0549(0.0337)$ & & 0.49 & 0.0360 & -37.52 \\
\hline $\mathrm{R}=a+b \mathrm{LST}+c \mathrm{SR}$ & $-0.8574(0.6490)$ & $0.0720(0.0254)$ & $0.001438(0.001650)$ & & 0.49 & 0.0362 & -37.51 \\
\hline $\mathrm{R}=a+b \mathrm{P}+c \mathrm{SR}$ & $1.1455(0.4142)$ & $-0.0029(0.0012)$ & $0.0014(0.0018)$ & & 0.38 & 0.0889 & -35.17 \\
\hline $\mathrm{R}=a+b \mathrm{P}+c \mathrm{LST}+d \mathrm{SR}$ & $-0.2875(0.9843)$ & $-0.0012(0.0016)$ & $0.0544(0.0343)$ & $0.0013(0.0017)$ & 0.52 & 0.0754 & -36.36 \\
\hline
\end{tabular}

Note. Models performed using precipitation $\left(\mathrm{P}, \mathrm{mm} \mathrm{month}^{-1}\right)$, land surface temperature (LST, $\left.{ }^{\circ} \mathrm{C}\right)$, and solar radiation $\left(\mathrm{SR}, \mathrm{W} \mathrm{m}^{-2}\right)$ as factors. The adjustment coefficients $(a, b, c$, and $d)$ of the linear models are shown as mean (standard error). The statistical parameters are: Pearson coefficient of determination $\left(r^{2}\right)$, $p$-value, and AIC.

AIC, Akaike information criteria; GPP, gross primary productivity; NPP, net primary productivity; R, autotrophic respiration.

Caution must be exercised on the interpretation of our results because they are based on a limited number of outcomes. In addition, remote sensing-based methods tend to underestimate NPP over dense canopies and at high productivity sites (Huete et al., 2002; de Oliveira et al., 2017; Šímová \& Storch, 2017; Turner et al., 2005; Turner, Ritts, Cohen, et al., 2006; Turner, Ritts, Zhao, et al., 2006), which makes our results conservative since undisturbed systems displayed higher values of NPP than in drought disturbed areas (Figure 3). Although other uncertainties in meteorological inputs are higher in tropics because of the inadequate weather station coverage and small-scale convection processes, reflectance measurement biases due to dense clouds are minimized in the improved MOD17A3 product using a year-end post-processing (Running \& Zhao, 2015; Running et al., 2015; Zhao et al., 2005). The MOD17 products undergo post-process LAI/FPAR gap-filling at the end of each annual cycle to correct for biases that specifically impact persistent cloud areas. The differences in the daily climatology inputs to MOD17 are the root cause of the differences in interannual variability of Amazonia NPP; these differences extend to the global domain but are especially apparent over the tropics due to differences in the underlying land model assimilation framework used for the NCEP-II reanalysis (Maeda et al., 2016; Zhao \& Running, 2010) and the various versions of the GMAO Forward Processing system used for MOD17 (Lyapustin et al., 2014). The previous comparison between MODIS products suggests that differences in the land model/surface meteorological driver datasets are likely to overwhelm any change due to drought sensitivity (Lyapustin et al., 2014; Maeda et al., 2016), evidencing that the biases in the products do not vary with drought conditions. The fPAR response to drought is inconsistent and usually small after robust correction of confounding cloud and atmospheric factors (Yan et al., 2019; J. Yang, Tian, et al., 2018). Potential systematic inconsistencies in the magnitude of GPP/NPP 
a

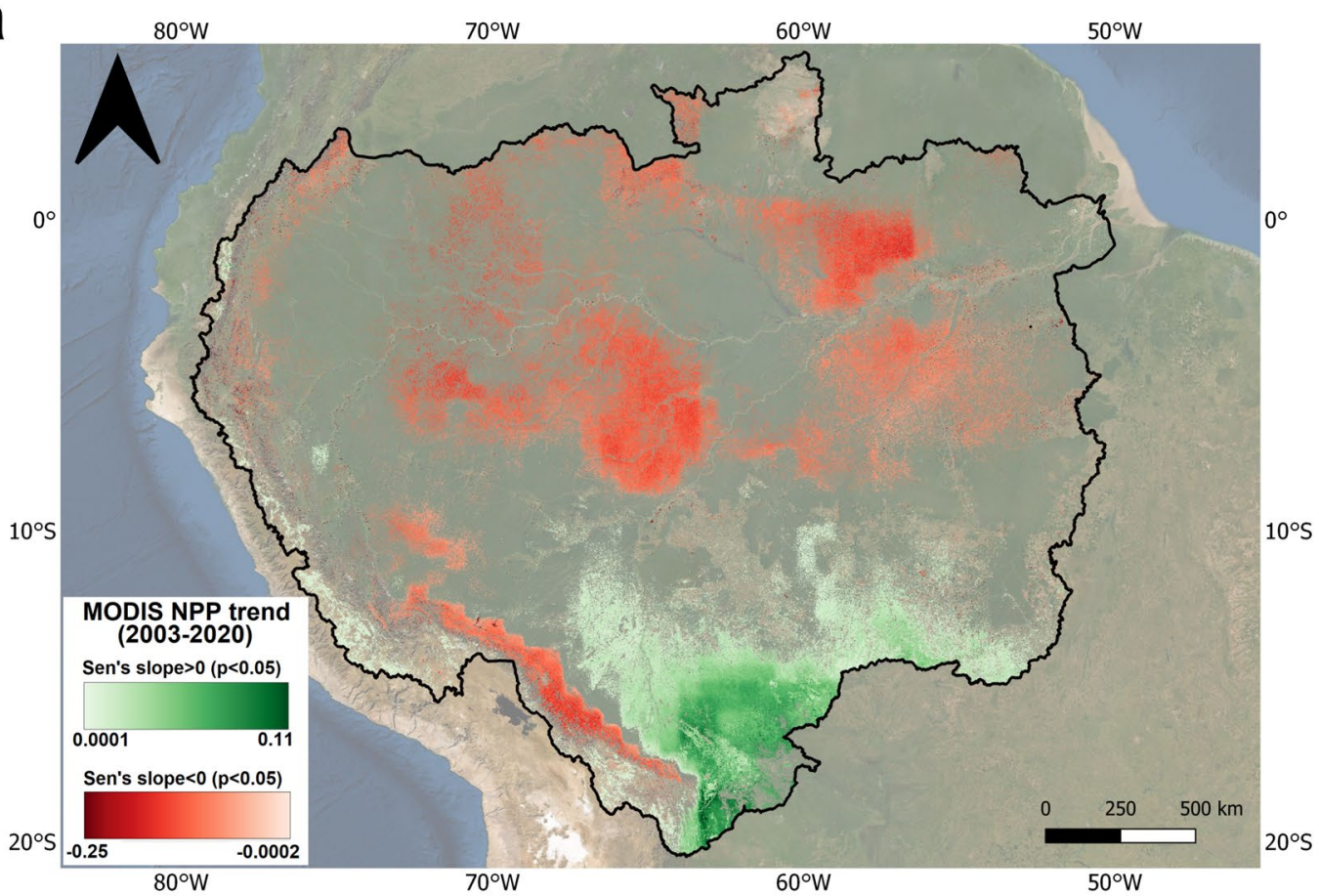

b

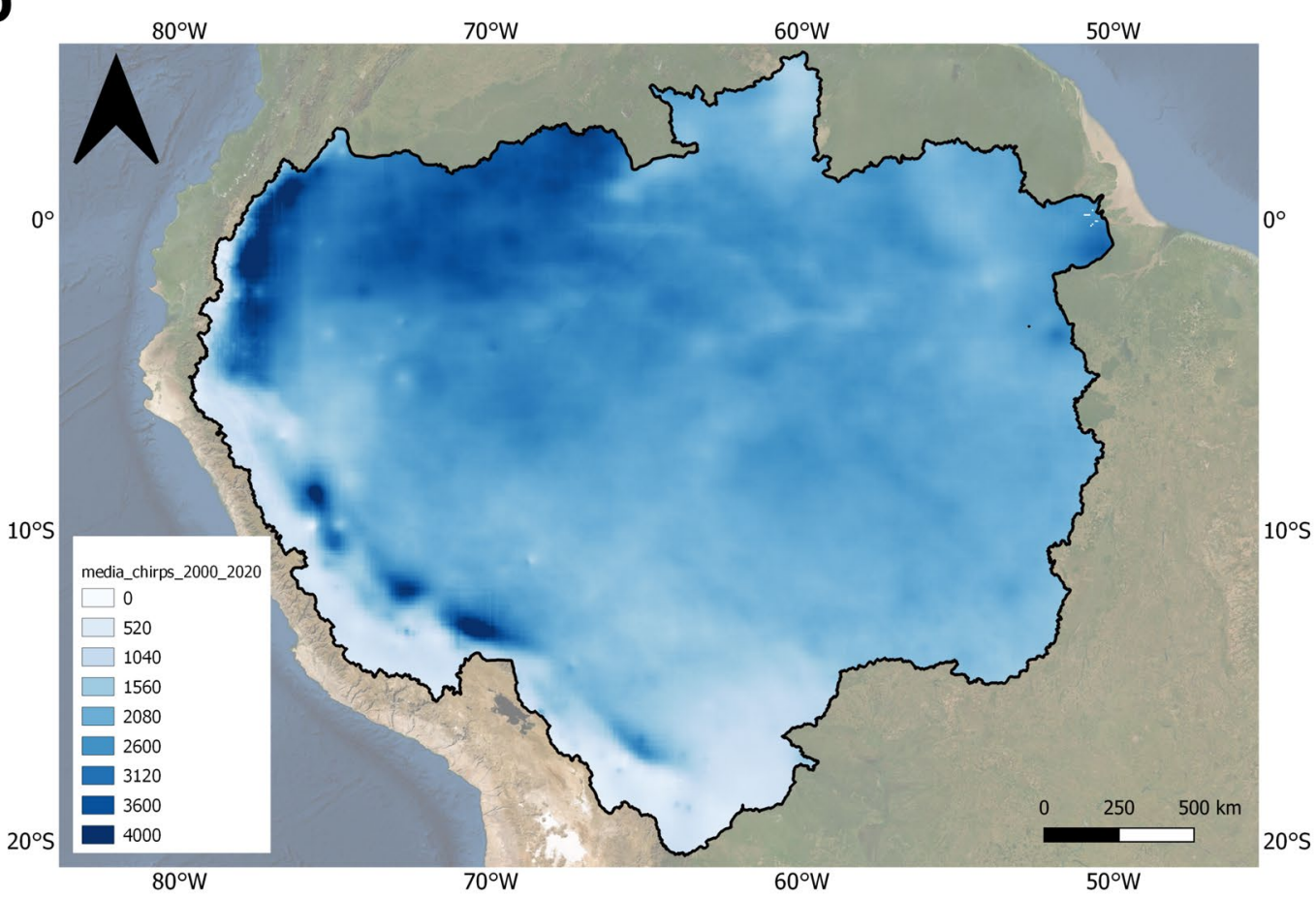

Figure 8. (a) Spatial trends of net primary productivity (NPP) in the Amazon basin. Green and red pixels indicate significantly increasing and decreasing NPP $\left(\mathrm{kg} \mathrm{C} \mathrm{m}^{-2} \mathrm{y}^{-1}\right)$ trends, respectively, for the period 2003-2020. (b) Annual precipitation $\left(\mathrm{mm} \mathrm{y}^{-1}\right)$ spatially distributed across the Amazon basin based on CHIRPS. 


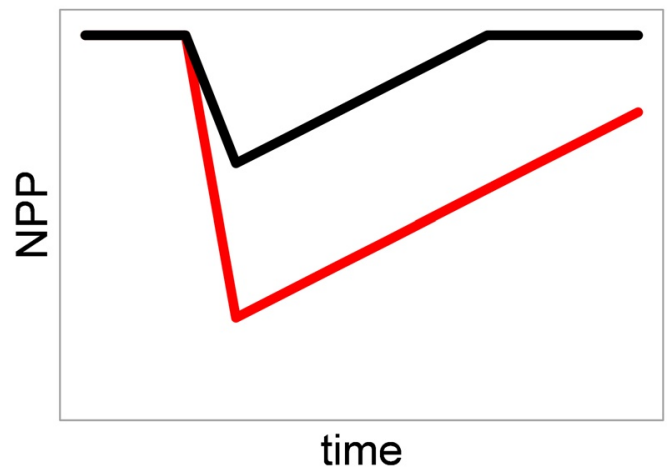

b

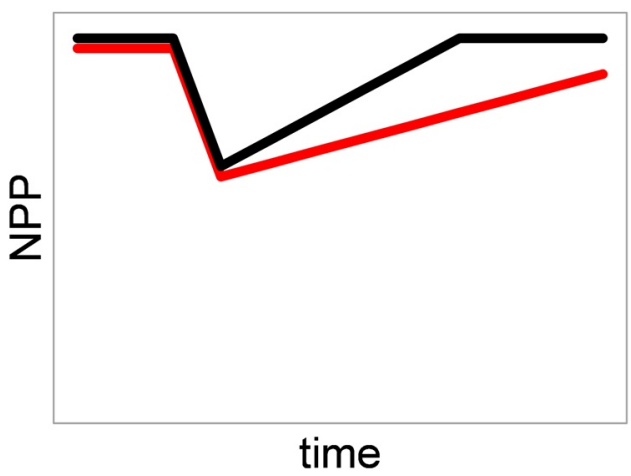

Figure 9. Conceptual model of mechanisms for increasing recovery debts: (a) increase in magnitude of disturbance and (b) decrease in recovery rates.

ratio obtained using MODIS products ought not to affect the detection accuracy for patterns of relative interannual variations in GPP/NPP (Zhao \& Running, 2010, 2011).

Overall, disturbance and recovery shape the dynamics of many forested biomes (Ghazoul \& Chazdon, 2017; Johnstone et al., 2016; Moreno-Mateos et al., 2017; Ogle et al., 2015) and climate change can reduce terrestrial water storage in many parts of the globe (Pokhrel et al., 2021) and a more intense reduction is anticipated for the Amazon basin (Davidson et al., 2012; Duffy et al., 2015; Saatchi et al., 2021). Modeling research has projected that climate change may push the rainforest towards a savanna-like ecosystem (Davidson et al., 2012; Hirota et al., 2011). Some models indicate that tipping points for rainforest-climate equilibrium may exist for the total deforested area $(>40 \%)$ and global warming $\left(\Delta \mathrm{T}>3-4^{\circ} \mathrm{C}\right)$ (Nobre et al., 2016). Indeed, Amazon $C$ has been accumulating at a decreasing rate (Brienen et al., 2015; Gatti et al., 2021), and there is a risk of a self-amplified, nonlinear increase in forest loss under conditions of decreased rainfall (Zemp et al., 2017). Our findings indicate an increase in recovery debts and that shortening of the time for rainforest recovery between consecutive droughts may push basin-wide C-uptake decline beyond the ecosystem resilience threshold. The projected increase in temperature and an increase in drought intensity (Duffy et al., 2015; Pokhrel et al., 2021) may result in a further decrease in the $\mathrm{C}$ sequestration capacity of the biome feeding back carbon to the atmosphere.

\section{Conclusions}

Important relations between drought and vegetation productivity have been identified as forcing for forest change. To date, we show the mechanisms triggering those impacts, particularly concerning (a) the level to which drought, as an isolated event, can shape forest productivity and (b) the extent to which extreme drought can have long-lasting effects on vegetation recovery since the past can influence the present trajectory of ecosystems (Figure 9). Our analysis shows that the outcome of an extreme drought event depends not only on rainfall scarcity in that year but also on the ecosystem functioning during recovery. Our results underscore the need to consider the post-drought impacts on Amazon NPP and highlight the crucial need to analyze the interim reduction of ecological processes at a broad scale to reveal an integrated legacy of droughts that are becoming more intense and frequent worldwide.

\section{Data Availability Statement}

NPP, GPP, R, and LST data are available at lpdaac.usgs.gov. TRMM data are available at disc.gsfc.nasa.gov. Solar radiation data are available at ecmwf.int. CHIRPS data are available at data.chc.ucsb.edu. 


\section{Acknowledgments}

Fausto Machado-Silva was supported by the FAPERJ postdoctoral fellowship (E26/203.174/2016) and CNPq (152325/2020-4); Renata Libonati was supported by CNPq (Grant 05159/20186), and FAPERJ (Grant 202.714/2019); Humberto Marotta was supported by FAPERJ (2033042017), CNPq (31015220178), and CAPES (Finance Code 001); Roberta B. Peixoto was supported by CAPES (Finance Code 001) and the Serrapilheira Institute postdoctoral fellowship Serra-1708-15159). The Portuguese Foundation for Science and Technology (FCT) supported CEF (UIDB/00239/2020) and IDL (UIDB/50019/2020-IDL). The authors thank Felipe Santos for the map of the Amazon vegetation types, and John Kimball and Arthur Endsley for technical support with MODIS products.

\section{References}

Allen, C. D., Breshears, D. D., \& McDowell, N. G. (2015). On underestimation of global vulnerability to tree mortality and forest die-off from hotter drought in the Anthropocene. Ecosphere, 6(8), 1-55. https://doi.org/10.1890/es15-00203.1

Anderegg, W. R. L., Schwalm, C., Biondi, F., Camarero, J. J., Koch, G., Litvak, M., et al. (2015). Pervasive drought legacies in forest ecosystems and their implications for carbon cycle models. Science, 349(6247), 528-532. https://doi.org/10.1126/science.aab1833

Anderegg, W. R. L., Trugman, A. T., Badgley, G., Konings, A. G., \& Shaw, J. (2020). Divergent forest sensitivity to repeated extreme droughts. Nature Climate Change, 10(12), 1091-1095. https://doi.org/10.1038/s41558-020-00919-1

Anderson, L. O., Ribeiro Neto, G., Cunha, A. P., Fonseca, M. G., Mendes de Moura, Y., Dalagnol, R., et al. (2018). Vulnerability of Amazonian forests to repeated droughts. Philosophical Transactions of the Royal Society B: Biological Sciences, 373(1760), 20170411. https://doi. org/10.1098/rstb.2017.0411

Asner, G. P., Nepstad, D., Cardinot, G., \& Ray, D. (2004). From the cover: Drought stress and carbon uptake in an Amazon forest measured with spaceborne imaging spectroscopy. Proceedings of the National Academy of Sciences, 101(16), 6039-6044. https://doi.org/10.1073/ pnas.0400168101

Banimahd, S. A., \& Khalili, D. (2013). Factors influencing Markov chains predictability characteristics, utilizing SPI, RDI, EDI and SPEI drought indices in different climatic zones. Water Resources Management, 27(11), 3911-3928. https://doi.org/10.1007/s11269-013-0387-z

Barkhordarian, A., Saatchi, S. S., Behrangi, A., Loikith, P. C., \& Mechoso, C. R. (2019). A recent systematic increase in vapor pressure deficit over Tropical South America. Scientific Reports, 9(1), 15331. https://doi.org/10.1038/s41598-019-51857-8

Brienen, R. J. W., Phillips, O. L., Feldpausch, T. R., Gloor, E., Baker, T. R., Lloyd, J., et al. (2015). Long-term decline of the Amazon carbon sink. Nature, 519(7543), 344-348. https://doi.org/10.1038/nature14283

Chandler, R. E., \& Scott, E. M. (2011). Statistical methods for trend detection and analysis in the environmental sciences. In R. E. Chandler, \& E. M. Scott (Eds.), Statistical methods for trend detection and analysis in the environmental Sciences. John Wiley \& Sons, Ltd. https:// doi.org/10.1002/9781119991571

Chen, T., van der Werf, G. R., de Jeu, R., Wang, G., \& Dolman, A. (2013). A global analysis of the impact of drought on net primary productivity. Hydrology and Earth System Sciences, 17(10), 3885-3894. https://doi.org/10.5194/hess-17-3885-2013

Chen, Z., Wang, W., Yu, Z., Xia, J., \& Schwartz, F. W. (2020). The collapse points of increasing trend of vegetation rain-use efficiency under droughts. Environmental Research Letters, 15(10), 104072. https://doi.org/10.1088/1748-9326/abb332

Ciemer, C., Boers, N., Hirota, M., Kurths, J., Müller-Hansen, F., Oliveira, R. S., \& Winkelmann, R. (2019). Higher resilience to climatic disturbances in tropical vegetation exposed to more variable rainfall. Nature Geoscience, 12(3), 174-179. https://doi.org/10.1038/ s41561-019-0312-z

Coe, M. T., Macedo, M. N., Brando, P. M., Lefebvre, P., Panday, P., \& Silvério, D. (2016). The hydrology and energy balance of the Amazon basin. In Interactions between biosphere, atmosphere and human land use in the Amazon basin (pp. 35-53). Springer. https://doi. org/10.1007/978-3-662-49902-3_3

da Costa, A. C. L., Metcalfe, D. B., Doughty, C. E., de Oliveira, A. A. R., Neto, G. F. C., da Costa, M. C., et al. (2014). Ecosystem respiration and net primary productivity after 8-10 years of experimental through-fall reduction in an eastern Amazon forest. Plant Ecology \& Diversity, 7(1-2), 7-24. https://doi.org/10.1080/17550874.2013.798366

Davidson, E. A., Araújo, A. C., Artaxo, P., Balch, J. K., Brown, I. F., Bustamante, M. M. C., et al. (2012). The Amazon basin in transition. Nature, 481(7381), 321-328. https://doi.org/10.1038/nature10717

Dee, D. P., Uppala, S. M., Simmons, A. J., Berrisford, P., Poli, P., Kobayashi, S., et al. (2011). The ERA-Interim reanalysis: Configuration and performance of the data assimilation system. Quarterly Journal of the Royal Meteorological Society, 137(656), 553-597. https://doi. org/10.1002/qj. 828

de Oliveira, G., Brunsell, N. A., Moraes, E. C., Shimabukuro, Y. E., Bertani, G., dos Santos, T. V., \& Aragao, L. E. O. C. (2017). Evaluation of MODIS-based estimates of water-use efficiency in Amazonia. International Journal of Remote Sensing, 38(19), 5291-5309. https://doi. org/10.1080/01431161.2017.1339924

Doughty, C. E., Metcalfe, D. B., Girardin, C. A. J., Amézquita, F. F., Cabrera, D. G., Huasco, W. H., et al. (2015). Drought impact on forest carbon dynamics and fluxes in Amazonia. Nature, 519(7541), 78-82. https://doi.org/10.1038/nature14213

Doughty, R., Köhler, P., Frankenberg, C., Magney, T. S., Xiao, X., Qin, Y., et al. (2019). TROPOMI reveals dry-season increase of solar-induced chlorophyll fluorescence in the Amazon forest. Proceedings of the National Academy of Sciences, 116(44), 22393-22398. https:// doi.org/10.1073/pnas.1908157116

Doughty, R., Xiao, X., Qin, Y., Wu, X., Zhang, Y., \& Moore, B., III. (2021). Small anomalies in dry-season greenness and chlorophyll fluorescence for Amazon moist tropical forests during El Niño and La Niña. Remote Sensing of Environment, 253, 112196. https://doi. org/10.1016/j.rse.2020.112196

Duffy, P. B., Brando, P., Asner, G. P., \& Field, C. B. (2015). Projections of future meteorological drought and wet periods in the Amazon. Proceedings of the National Academy of Sciences, 112(43), 13172-13177. https://doi.org/10.1073/pnas.1421010112

Feldpausch, T. R., Phillips, O. L., Brienen, R. J. W., Gloor, E., Lloyd, J., Lopez-Gonzalez, G., et al. (2016). Amazon forest response to repeated droughts. Global Biogeochemical Cycles, 30(7), 964-982. https://doi.org/10.1002/2015GB005133

Friedlingstein, P., Jones, M. W., O'Sullivan, M., Andrew, R. M., Hauck, J., Peters, G. P., et al. (2019). Global carbon budget 2019. Earth System Science Data, 11(4), 1783-1838. https://doi.org/10.5194/essd-11-1783-2019

Funk, C., Peterson, P., Landsfeld, M., Pedreros, D., Verdin, J., Shukla, S., et al. (2015). The climate hazards infrared precipitation with stations-A new environmental record for monitoring extremes. Scientific Data, 2, 150066. https://doi.org/10.1038/sdata.2015.66

Gatti, L. V., Basso, L. S., Miller, J. B., Gloor, M., Gatti Domingues, L., Cassol, H. L. G., et al. (2021). Amazonia as a carbon source linked to deforestation and climate change. Nature, 595(7867), 388-393. https://doi.org/10.1038/s41586-021-03629-6

Gatti, L. V., Gloor, M., Miller, J. B., Doughty, C. E., Malhi, Y., Domingues, L. G., et al. (2014). Drought sensitivity of Amazonian carbon balance revealed by atmospheric measurements. Nature, 506(7486), 76-80. https://doi.org/10.1038/nature12957

Ghazoul, J., \& Chazdon, R. (2017). Degradation and recovery in changing forest landscapes: A multiscale conceptual framework. Annual Review of Environment and Resources, 42, 161-188. https://doi.org/10.1146/annurev-environ-102016-060736

Giardina, F., Konings, A. G., Kennedy, D., Alemohammad, S. H., Oliveira, R. S., Uriarte, M., \& Gentine, P. (2018). Tall Amazonian forests are less sensitive to precipitation variability. Nature Geoscience, 11(6), 405-409. https://doi.org/10.1038/s41561-018-0133-5

Gonçalves, N. B., Lopes, A. P., Dalagnol, R., Wu, J., Pinho, D. M., \& Nelson, B. W. (2020). Both near-surface and satellite remote sensing confirm drought legacy effect on tropical forest leaf phenology after 2015/2016 ENSO drought. Remote Sensing of Environment, 237, 111489. https://doi.org/10.1016/j.rse.2019.111489 
Guan, K., Pan, M., Li, H., Wolf, A., Wu, J., Medvigy, D., et al. (2015). Photosynthetic seasonality of global tropical forests constrained by hydroclimate. Nature Geoscience, 8(4), 284-289. https://doi.org/10.1038/ngeo2382

Gunderson, L. H. (2000). Ecological resilience-In theory and application. Annual Review of Ecology and Systematics, 31(1), $425-439$. https://doi.org/10.1146/annurev.ecolsys.31.1.425

Hilker, T., Lyapustin, A. I., Tucker, C. J., Hall, F. G., Myneni, R. B., Wang, Y., et al. (2014). Vegetation dynamics and rainfall sensitivity of the Amazon. Proceedings of the National Academy of Sciences, 111(45), 16041-16046. https://doi.org/10.1073/pnas.1404870111

Hirota, M., Holmgren, M., Van Nes, E. H., \& Scheffer, M. (2011). Global resilience of tropical forest and savanna to critical transitions. Science, 334(6053), 232-235. https://doi.org/10.1126/science.1210657

Hoegh-Guldberg, O., Jacob, D., Taylor, M., Bindi, M., Brown, S., Camilloni, I., et al. (2018). Impacts of $1.5^{\circ} \mathrm{C}$ of global warming on natural and human systems. In V. Masson-Delmotte, P. Zhai, H.-O. Pörtner, D. Roberts, J. Skea, P. R. Shukla, et al. (Eds.), Global Warming of $1.5^{\circ} \mathrm{C}$. An IPCC special report on the impacts of global warming of $1.5^{\circ} \mathrm{C}$ above pre-industrial levels and related global greenhouse gas emission pathways, in the context of strengthening the global response to the threat of climate change (1st ed., pp. 175-311). World Meteorological Organization.

Holling, C. S. (1973). Resilience and stability of ecological systems. Annual Review of Ecology and Systematics, 4(1), 1-23. https://doi. org/10.1146/annurev.es.04.110173.000245

Holling, C. S. (1996). Engineering within ecological constraints (Vol. 31). National Academies Press. https://doi.org/10.17226/4919

Huang, M., Piao, S., Ciais, P., Peñuelas, J., Wang, X., Keenan, T. F., et al. (2019). Air temperature optima of vegetation productivity across global biomes. Nature Ecology \& Evolution, 3(5), 772-779. https://doi.org/10.1038/s41559-019-0838-X

Huete, A., Didan, K., Miura, T., Rodriguez, E., Gao, X., \& Ferreira, L. (2002). Overview of the radiometric and biophysical performance of the MODIS vegetation indices. Remote Sensing of Environment, 83(1-2), 195-213. https://doi.org/10.1016/S0034-4257(02)00096-2

Huffman, G. J., Bolvin, D. T., Nelkin, E. J., Wolff, D. B., Adler, R. F., Gu, G., et al. (2007). The TRMM Multisatellite Precipitation Analysis (TMPA): Quasi-global, multiyear, combined-sensor precipitation estimates at fine scales. Journal of Hydrometeorology, 8(1), 38-55. https://doi.org/10.1175/JHM560.1

Jiménez-Muñoz, J. C., Mattar, C., Barichivich, J., Santamaría-Artigas, A., Takahashi, K., Malhi, Y., et al. (2016). Record-breaking warming and extreme drought in the Amazon rainforest during the course of El Niño 2015-2016. Scientific Reports, 6(1), 33130. https://doi. org/10.1038/srep33130

Johnstone, J. F., Allen, C. D., Franklin, J. F., Frelich, L. E., Harvey, B. J., Higuera, P. E., et al. (2016). Changing disturbance regimes, ecological memory, and forest resilience. Frontiers in Ecology and the Environment, 14(7), 369-378. https://doi.org/10.1002/fee.1311

Kendall, M. G. (1938). A new measure of rank correlation. Biometrika, 30(1/2), 81-93. https://doi.org/10.2307/2332226

Levine, N. M., Zhang, K., Longo, M., Baccini, A., Phillips, O. L., Lewis, S. L., et al. (2016). Ecosystem heterogeneity determines the ecological resilience of the Amazon to climate change. Proceedings of the National Academy of Sciences, 113(3), 793-797. https://doi. org/10.1073/pnas.1511344112

Lewis, S. L., Brando, P. M., Phillips, O. L., vander Heijden, G. M. F., \& Nepstad, D. (2011). The 2010 Amazon drought. Science, 331(6017), 554. https://doi.org/10.1126/science.1200807

Li, X., Piao, S., Wang, K., Wang, X., Wang, T., Ciais, P., et al. (2020). Temporal trade-off between gymnosperm resistance and resilience increases forest sensitivity to extreme drought. Nature Ecology \& Evolution, 4(8), 1075-1083. https://doi.org/10.1038/s41559-020-1217-3

Li, X., Xiao, J., \& He, B. (2018). Higher absorbed solar radiation partly offset the negative effects of water stress on the photosynthesis of Amazon forests during the 2015 drought. Environmental Research Letters, 13(4), 044005. https://doi.org/10.1088/1748-9326/aab0b1

Libonati, R., Pereira, J. M. C., Da Camara, C. C., Peres, L. F., Oom, D., Rodrigues, J. A., et al. (2021). Twenty-first century droughts have not increasingly exacerbated fire season severity in the Brazilian Amazon. Scientific Reports, 11(1), 4400. https://doi.org/10.1038/ s41598-021-82158-8

Lyapustin, A., Wang, Y., Xiong, X., Meister, G., Platnick, S., Levy, R., et al. (2014). Scientific impact of MODIS C5 calibration degradation and C6+ improvements. Atmospheric Measurement Techniques, 7(12), 4353-4365. https://doi.org/10.5194/amt-7-4353-2014

Maeda, E. E., Moura, Y. M., Wagner, F., Hilker, T., Lyapustin, A. I., Wang, Y., et al. (2016). Consistency of vegetation index seasonality across the Amazon rainforest. International Journal of Applied Earth Observation and Geoinformation, 52, 42-53. https://doi.org/10.1016/j. jag.2016.05.005

Mann, H. B. (1945). Nonparametric tests against trend. Econometrica, 13(3), 245-259. https://doi.org/10.2307/1907187

Marengo, J. A., Nobre, C. A., Tomasella, J., Oyama, M. D., Sampaiode Oliveira, G., de Oliveira, R., et al. (2008). The drought of Amazonia in 2005. Journal of Climate, 21(3), 495-516. https://doi.org/10.1175/2007JCLI1600.1

Marengo, J. A., Tomasella, J., Alves, L. M., Soares, W. R., \& Rodriguez, D. A. (2011). The drought of 2010 in the context of historical droughts in the Amazon region. Geophysical Research Letters, 38(12), L12703. https://doi.org/10.1029/2011GL047436

McKee, T. B., Doesken, N. J., \& Kleist, J. (1993). The relationship of drought frequency and duration to time scales. Proceedings of the 8th Conference on Applied Climatology (Vol. 17, pp. 179-183).

Mildrexler, D. J., Zhao, M., \& Running, S. W. (2009). Testing a MODIS global disturbance index across North America. Remote Sensing of Environment, 113(10), 2103-2117. https://doi.org/10.1016/j.rse.2009.05.016

Moreno-Mateos, D., Barbier, E. B., Jones, P. C., Jones, H. P., Aronson, J., López-López, J. A., et al. (2017). Anthropogenic ecosystem disturbance and the recovery debt. Nature Communications, 8(1), 14163. https://doi.org/10.1038/ncomms14163

Nemani, R. R., Keeling, C. D., Hashimoto, H., Jolly, W. M., Piper, S. C., Tucker, C. J., et al. (2003). Climate-driven increases in global terrestrial net primary production from 1982 to 1999. Science, 300(5625), 1560-1563. https://doi.org/10.1126/science.1082750

Nobre, C. A., Sampaio, G., Borma, L. S., Castilla-Rubio, J. C., Silva, J. S., \& Cardoso, M. (2016). Land-use and climate change risks in the Amazon and the need of a novel sustainable development paradigm. Proceedings of the National Academy of Sciences, 113(39), 10759-10768. https://doi.org/10.1073/pnas.1605516113

Ogle, K., Barber, J. J., Barron-Gafford, G. A., Bentley, L. P., Young, J. M., Huxman, T. E., et al. (2015). Quantifying ecological memory in plant and ecosystem processes. Ecology Letters, 18(3), 221-235. https://doi.org/10.1111/ele.12399

Panisset, J. S., Libonati, R., Gouveia, C. M. P., Machado-Silva, F., França, D. A., França, J. R. A., \& Peres, L. F. (2018). Contrasting patterns of the extreme drought episodes of 2005, 2010 and 2015 in the Amazon Basin. International Journal of Climatology, 38(2), 1096-1104. https://doi.org/10.1002/joc.5224

Phillips, O. L., Aragao, L. E. O. C., Lewis, S. L., Fisher, J. B., Lloyd, J., Lopez-Gonzalez, G., et al. (2009). Drought sensitivity of the Amazon rainforest. Science, 323(5919), 1344-1347. https://doi.org/10.1126/science.1164033

Pokhrel, Y., Felfelani, F., Satoh, Y., Boulange, J., Burek, P., Gädeke, A., et al. (2021). Global terrestrial water storage and drought severity under climate change. Nature Climate Change, 11(3), 226-233. https://doi.org/10.1038/s41558-020-00972-w 
Ponce-Campos, G. E., Moran, M. S., Huete, A., Zhang, Y., Bresloff, C., Huxman, T. E., et al. (2013). Ecosystem resilience despite large-scale altered hydroclimatic conditions. Nature, 494(7437), 349-352. https://doi.org/10.1038/nature11836

Poorter, L., Bongers, F., Aide, T. M., Almeyda Zambrano, A. M., Balvanera, P., Becknell, J. M., et al. (2016). Biomass resilience of Neotropical secondary forests. Nature, 530(7589), 211-214. https://doi.org/10.1038/nature16512

$\mathrm{R}$ Core Team. (2020). R: A language and environment for statistical computing. R Foundation for Statistical Computing. Retrieved from https://www.r-project.org

Restrepo-Coupe, N., Da Rocha, H. R., Hutyra, L. R., Da Araujo, A. C., Borma, L. S., Christoffersen, B., et al. (2013). What drives the seasonality of photosynthesis across the Amazon basin? A cross-site analysis of eddy flux tower measurements from the Brasil flux network. Agricultural and Forest Meteorology, 182, 128-144. https://doi.org/10.1016/j.agrformet.2013.04.031

Restrepo-Coupe, N., Levine, N. M., Christoffersen, B. O., Albert, L. P., Wu, J., Costa, M. H., et al. (2017). Do dynamic global vegetation models capture the seasonality of carbon fluxes in the Amazon basin? A data-model intercomparison. Global Change Biology, 23(1), 191-208. https://doi.org/10.1111/gcb.13442

Running, S., \& Zhao, M. (2011). Note to users on use of MODIS GPP/NPP (MOD17) datasets.

Running, S. W., Mu, Q., \& Zhao, M. (2011). MOD17A3 MODIS/Terra net primary production yearly L4 global $1 \mathrm{~km}$ SIN gid V055 [Data set]. NASA EOSDIS Land Processes DAAC.

Running, S. W., Mu, Q., \& Zhao, M. (2015). MOD17A3H MODIS/Terra Net primary production yearly L4 global 500m SIN grid V006. NASA EOSDIS Land Processes DAAC.

Running, S. W., Nemani, R., Glassy, J. M., \& Thornton, P. E. (1999). MODIS daily photosynthesis (PSN) and annual net primary production (NPP) product (MOD17) algorithm theoretical basis document. University of Montana. SCF At-Launch Algorithm ATBD Documents.

Running, S. W., Nemani, R. R., Heinsch, F. A., Zhao, M., Reeves, M., \& Hashimoto, H. (2004). A continuous satellite-derived measure of global terrestrial primary production. BioScience, 54(6), 547-560. https://doi.org/10.1641/0006-3568(2004)054[0547:ACSMOG]2.0.CO;2

Running, S. W., \& Zhao, M. (2015). Daily GPP and annual NPP (MOD17A2/A3) products NASA Earth Observing System MODIS land algorithm. MOD17 User's Guide.

Saatchi, S. S., Houghton, R. A., Dod Santos Alvala, R. C., Soares, J. V., \& Yu, Y. (2007). Distribution of aboveground live biomass in the Amazon basin. Global Change Biology, 13(4), 816-837. https://doi.org/10.1111/j.1365-2486.2007.01323.X

Saatchi, S. S., Longo, M., Xu, L., Yang, Y., Abe, H., André, M., et al. (2021). Detecting vulnerability of humid tropical forests to multiple stressors. One Earth, 4(7), 988-1003. https://doi.org/10.1016/j.oneear.2021.06.002

Sakschewski, B., von Bloh, W., Boit, A., Poorter, L., Peña-Claros, M., Heinke, J., et al. (2016). Resilience of Amazon forests emerges from plant trait diversity. Nature Climate Change, 6(11), 1032-1036. https://doi.org/10.1038/nclimate3109

Saleska, S. R., Didan, K., Huete, A. R., \& da Rocha, H. R. (2007). Amazon forests green-up during 2005 drought. Science, $318(5850)$, 612. https://doi.org/10.1126/science.1146663

Saleska, S. R., Wu, J., Guan, K., Araujo, A. C., Huete, A., Nobre, A. D., \& Restrepo-Coupe, N. (2016). Dry-season greening of Amazon forests. Nature, 531(7594), E4-E5. https://doi.org/10.1038/nature16457

Santos, V. A. H. F. d., Ferreira, M. J., Rodrigues, J. V. F. C., Garcia, M. N., Ceron, J. V. B., Nelson, B. W., \& Saleska, S. R. (2018). Causes of reduced leaf-level photosynthesis during strong El Niño drought in a Central Amazon forest. Global Change Biology, 24(9), 4266-4279. https://doi.org/10.1111/gcb.14293

Scheffer, M., Carpenter, S. R., Dakos, V., \& van Nes, E. H. (2015). Generic indicators of ecological resilience: Inferring the chance of a critical transition. Annual Review of Ecology, Evolution, and Systematics, 46, 145-167. https://doi.org/10.1146/annurev-ecolsys-112414-054242

Shumway, R. H., \& Stoffer, D. S. (2017). Time series analysis and its applications. In Remote sensing of environment (Vol. 83). Springer International Publishing. https://doi.org/10.1007/978-3-319-52452-8

Šímová, I., \& Storch, D. (2017). The enigma of terrestrial primary productivity: Measurements, models, scales and the diversity-productivity relationship. Ecography, 40(2), 239-252. https://doi.org/10.1111/ecog.02482

Smith, M. N., Taylor, T. C., van Haren, J., Rosolem, R., Restrepo-Coupe, N., Adams, J., et al. (2020). Empirical evidence for resilience of tropical forest photosynthesis in a warmer world. Nature Plants, 6(10), 1225-1230. https://doi.org/10.1038/s41477-020-00780-2

Sulla-Menashe, D., \& Friedl, M. A. (2018). User guide to collection 6 MODIS land cover (MCD12Q1 and MCD12C1) product (Figure 1, pp. $1-18)$.

Turner, D. P., Ritts, W. D., Cohen, W. B., Gower, S. T., Running, S. W., Zhao, M., et al. (2006). Evaluation of MODIS NPP and GPP products across multiple biomes. Remote Sensing of Environment, 102(3-4), 282-292. https://doi.org/10.1016/j.rse.2006.02.017

Turner, D. P., Ritts, W. D., Cohen, W. B., Maeirsperger, T. K., Gower, S. T., Kirschbaum, A. A., et al. (2005). Site-level evaluation of satellite-based global terrestrial gross primary production and net primary production monitoring. Global Change Biology, 11(4), 666-684. https://doi.org/10.1111/j.1365-2486.2005.00936.x

Turner, D. P., Ritts, W. D., Zhao, M., Kurc, S. A., Dunn, A. L., Wofsy, S. C., et al. (2006). Assessing interannual variation in MODIS-based estimates of gross primary production. IEEE Transactions on Geoscience and Remote Sensing, 44(7), 1899-1907. https://doi.org/10.1109/ TGRS.2006.876027

van Schaik, E., Killaars, L., Smith, N. E., Koren, G., van Beek, L. P. H., Peters, W., \& van der Laan-Luijkx, I. T. (2018). Changes in surface hydrology, soil moisture and gross primary production in the Amazon during the 2015/2016 El Niño. Philosophical Transactions of the Royal Society B: Biological Sciences, 373(1760), 20180084. https://doi.org/10.1098/rstb.2018.0084

Vicente-Serrano, S. M. M., Beguería, S., \& López-Moreno, J. I. (2010). A multiscalar drought index sensitive to global warming: The standardized precipitation evapotranspiration index. Journal of Climate, 23(7), 1696-1718. https://doi.org/10.1175/2009jcli2909.1

Vicente-Serrano, S. M. M., Gouveia, C., Camarero, J. J. J., Begueria, S., Trigo, R., Lopez-Moreno, J. I., et al. (2013). Response of vegetation to drought time-scales across global land biomes. Proceedings of the National Academy of Sciences, 110(1), 52-57. https://doi.org/10.1073/ pnas. 1207068110

Wan, Z. (2013). MODIS land surface temperature products users' guide.

Wigneron, J.-P., Fan, L., Ciais, P., Bastos, A., Brandt, M., Chave, J., et al. (2020). Tropical forests did not recover from the strong 2015-2016 El Niño event. Science Advances, 6(6), eaay4603. https://doi.org/10.1126/sciadv.aay4603

Williams, A., Allen, C. D., Macalady, A. K., Griffin, D., Woodhouse, C. A., Meko, D. M., et al. (2013). Temperature as a potent driver of regional forest drought stress and tree mortality. Nature Climate Change, 3(3), 292-297. https://doi.org/10.1038/nclimate1693

Yan, H., Wang, S., Huete, A., \& Shugart, H. H. (2019). Effects of light component and water stress on photosynthesis of Amazon rainforests during the 2015/2016 El Niño drought. Journal of Geophysical Research: Biogeosciences, 124(6), 1574-1590. https://doi.org/10.1029/2018jg004988 
Yang, J., Tian, H., Pan, S., Chen, G., Zhang, B., \& Dangal, S. (2018). Amazon drought and forest response: Largely reduced forest photosynthesis but slightly increased canopy greenness during the extreme drought of 2015/2016. Global Change Biology, 24(5), 1919-1934. https://doi.org/10.1111/gcb.14056

Yang, Y., Saatchi, S. S., Xu, L., Yu, Y., Choi, S., Phillips, N., et al. (2018). Post-drought decline of the Amazon carbon sink. Nature Communications, 9(1), 3172. https://doi.org/10.1038/s41467-018-05668-6

Yue, S., \& Wang, C. Y. (2002). Regional streamflow trend detection with consideration of both temporal and spatial correlation. International Journal of Climatology, 22(8), 933-946. https://doi.org/10.1002/joc.781

Zemp, D. C., Schleussner, C.-F., Barbosa, H. M. J., Hirota, M., Montade, V., Sampaio, G., et al. (2017). Self-amplified Amazon forest loss due to vegetation-atmosphere feedbacks. Nature Communications, 8(1), 14681. https://doi.org/10.1038/ncomms14681

Zhao, M., Heinsch, F. A., Nemani, R. R., \& Running, S. W. (2005). Improvements of the MODIS terrestrial gross and net primary production global data set. Remote Sensing of Environment, 95(2), 164-176. https://doi.org/10.1016/j.rse.2004.12.011

Zhao, M., \& Running, S. W. (2010). Drought-induced reduction in global terrestrial net primary production from 2000 through 2009 . Science, 329(5994), 940-943. https://doi.org/10.1126/science.1192666

Zhao, M., \& Running, S. W. (2011). Response to comments on "drought-induced reduction in global terrestrial net primary production from 2000 through 2009. Science, 333(6046), 1093. https://doi.org/10.1126/science.1199169 